(c) <2017>. This manuscript version is made available under the CC-BY-NC-ND

4.0 license http://creativecommons.org/licenses/by-nc-nd/4.0/

Numerical Investigation of the Energy Performance of an Opaque Ventilated Façade System Employing a Smart Modular Heat Recovery Unit and a Latent Heat Thermal Energy System

Thierno M.O. DIALLO ${ }^{\mathrm{a}, *}$, Xudong ZHAO ${ }^{\mathrm{a},{ }^{*} \text {, Antoine DUGUE }}{ }^{\mathrm{b}}$, Paul BONNAMY ${ }^{\mathrm{b}}$, Francisco Javier MIGUEL ${ }^{\mathrm{c}}$, Asier MARTINEZ ${ }^{\mathrm{d}}$, Theodoros THEODOSIOU ${ }^{\mathrm{e}}$, Jing-Sheng LIU $^{\mathrm{a}}$, Nathan BROWN ${ }^{\mathrm{a}}$ 


\title{
Numerical Investigation of the Energy Performance of an Opaque Ventilated Façade System Employing a Smart Modular Heat Recovery Unit and a Latent Heat Thermal Energy System
}

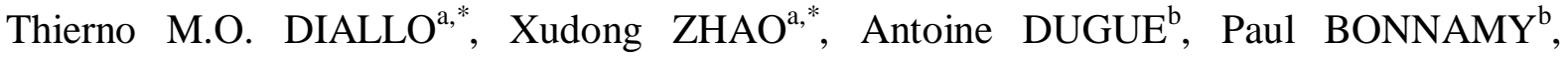 \\ Francisco Javier MIGUEL ${ }^{c}$, Asier MARTINEZ ${ }^{d}$, Theodoros THEODOSIOU ${ }^{\mathrm{e}}$, Jing-Sheng \\ LIU $^{\mathrm{a}}$, Nathan BROWN ${ }^{\mathrm{a}}$
}
${ }^{\text {a}}$ School of Engineering, University of Hull, United Kingdom.
${ }^{\mathrm{b}}$ Nobatek, 67, rue de Mirambeau, 64100 Anglet, France. ${ }^{\mathrm{c} C a r t i f}, 47151$ Boecillo, Valladolid, Spain.

${ }^{\mathrm{d}}$ Tecnalia, Energy and Environment Division, 20730 Azpeitia, Spain.

${ }^{\mathrm{e}}$ Aristotle University of Thessaloniki, Thessaloniki 541 24, Greece.

*Corresponding email: T.Diallo@hull.ac.uk, Xudong.Zhao@hull.ac.uk

\begin{abstract}
:
The building sector is responsible for more than $40 \%$ of the EU's total energy consumption. To reduce the energy consumption in buildings and to achieve the EU's fossil fuel saving targets for 2020 and beyond 2050, the energy efficient retrofitting strategies are critically important and need to be implemented effectively. This paper presents a dynamic numerical investigation of the energy performance of an innovative façade integrate-able energy efficient ventilation system (E2VENT) that incorporates a smart modular heat recovery unit (SMHRU) and a latent heat thermal energy system (LHTES). A number of component simulation models, including SMHRU, LHTES, Cladding and Building Energy Management System (BEMS), were developed and then integrated using the TRNSYS software which is an advanced building energy performance simulation tool. On this basis, sizing, optimisation and characterisation of the system elements including the HVAC system and insulation layer thickness were carried out. The overall energy efficiency of the E2VENT system and its impact on the energy performance of a post-retrofit building were then investigated. In particular, the heating and cooling energy performance of the E2VENT façade module was numerically studied at five different climatic conditions in Europe. Furthermore, the innovative E2VENT retrofitting was compared with traditional retrofittings in terms of the energy efficiency and primary energy savings. It was found that the innovative E2VENT
\end{abstract}


solution can achieve 16.5 to $23.5 \%$ building primary energy saving and compared to the traditional retrofitting, the E2VENT solution can achieve two times less primary energy consumption.

Keywords: Opaque Ventilated façade; Energy simulation; Smart Modular Heat Recovery Unit; Latent Heat Thermal Energy System; Building Energy Management System (BEMS).

\section{Highlights}

-An innovative E2VENT ventilated façade system is presented and studied

-A TRNSYS based global model for the E2VENT and its building integration is developed

-The energy efficiency of the system is assessed for five climatic conditions in Europe

-The E2VENT retrofitting is suggested and compared with a traditional retrofit method.

-The innovative E2VENT system could achieve 16.5 to $23.5 \%$ primary energy saving

-The E2VENT achieves two times less primary energy consumption compared to the traditional one

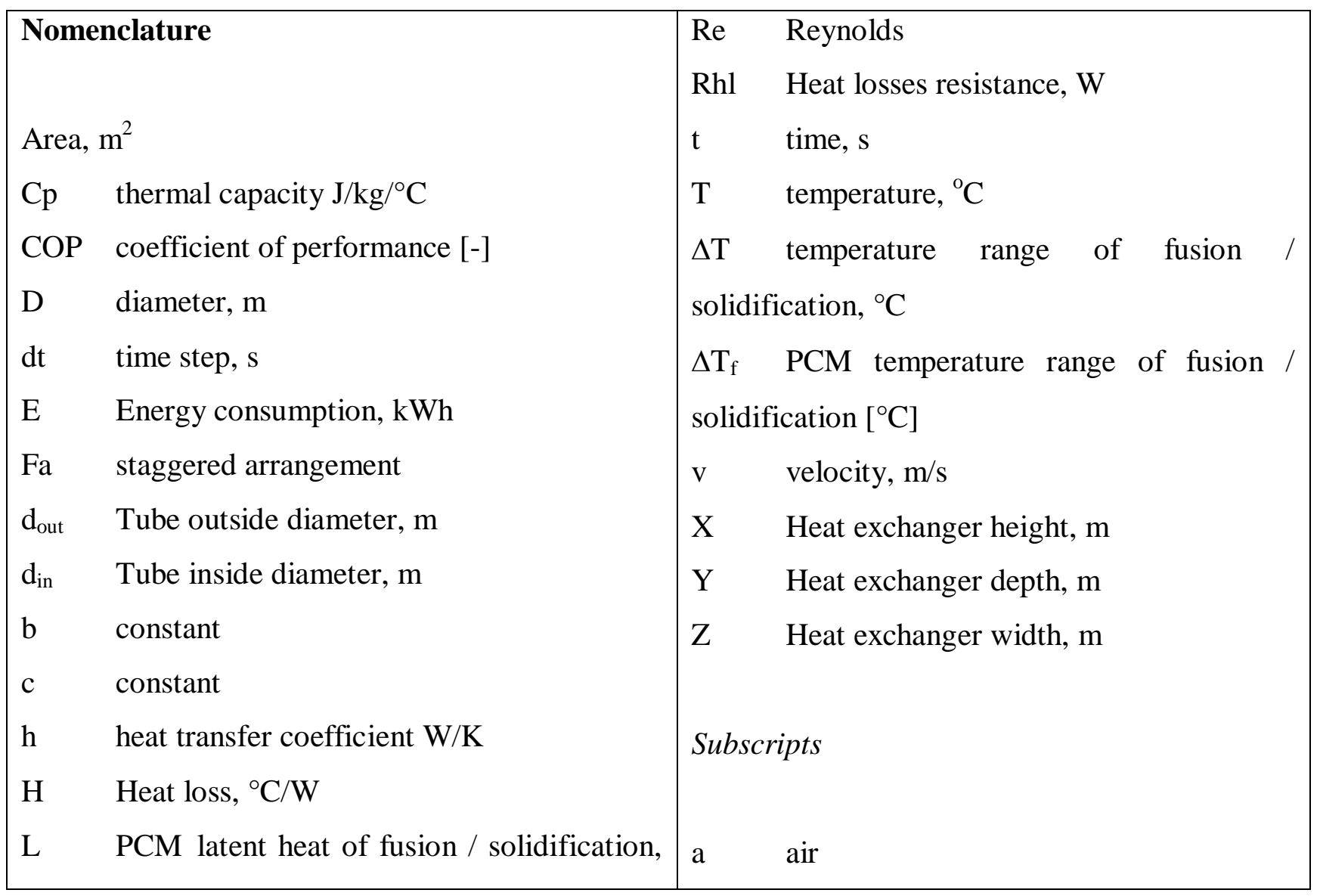




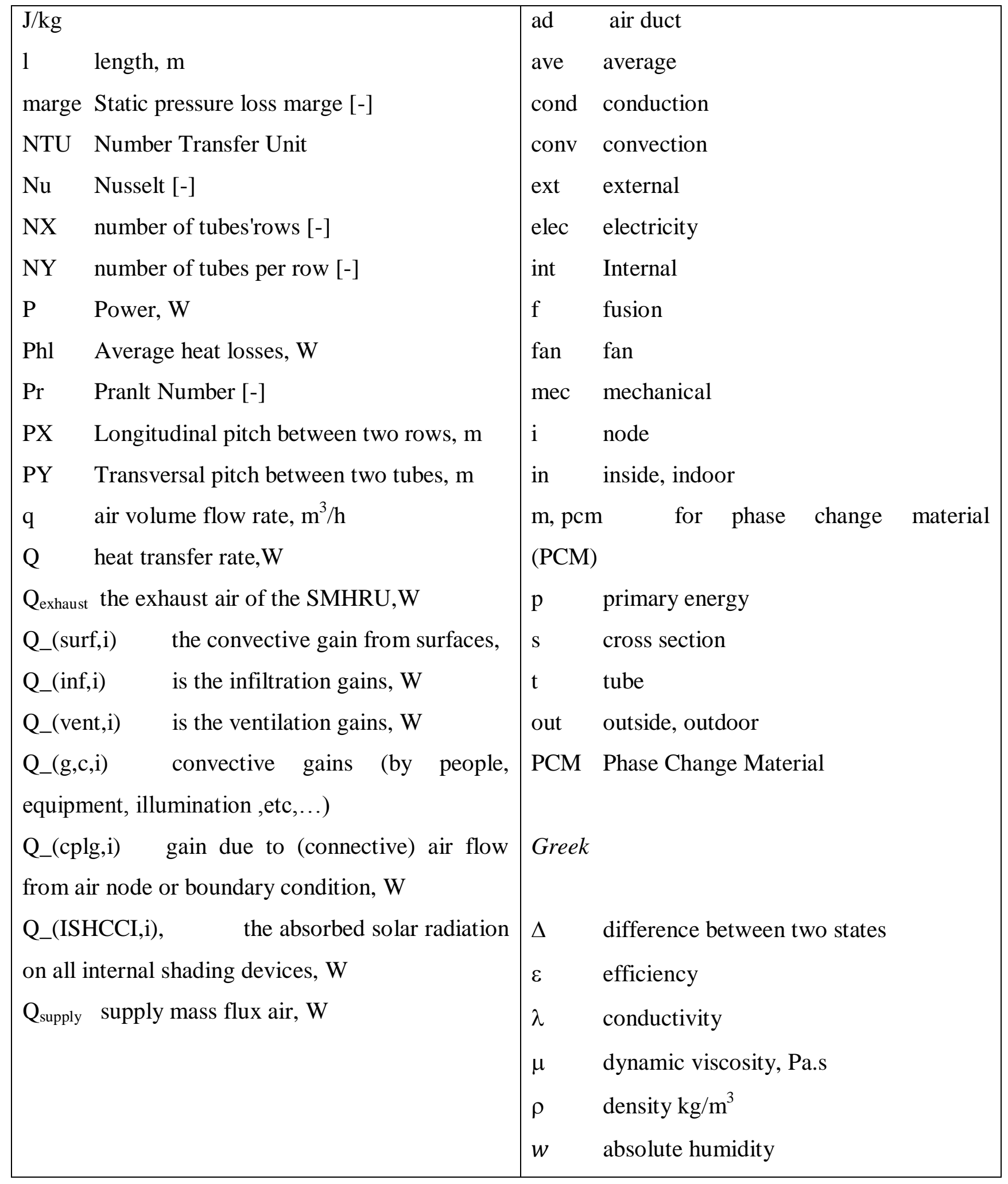




\section{Introduction}

Façade renovation is recognised as one of the most efficient strategies in reducing energy consumption in buildings. The ventilated façade, as one of the best solutions in managing the interaction between the outdoor and indoor environments [1], is getting the growing popularity owing to its effectiveness in energy saving, simplicity in implementation and relatively low cost. In recent years, several studies were undertaken on various ventilated facade types including Double Skin façades [2], integrated PV façades [3,4,5], façade solar collectors [6], Solar chimney and Trombe walls [7,8,9] etc. However, studies on Opaque Ventilated Façades (OVFs) have not yet been reported, possibly owing to their limited application (i.e., residential buildings only) [10]. An Opaque Ventilated Façade comprises three layers: an inner building envelope, an air cavity (ventilated naturally or mechanically) and an opaque external skin. Several experimental and numerical studies were undertaken in order to characterize the main factors affecting the thermal performance of these systems and their capacity to reduce heating and cooling loads. López and Santiago [11] carried out a numerical sensitivity study that is to address the efficiency of an OVF in winter for different climatic zones in Spain, indicating that the ventilated façade is best suited to the low winter severity climate. Further, solar radiation was found to be the most relating variable to energy efficiency of the façade, while the combination of high temperature and low wind speeds could lead to significant energy saving of the façade. López et al. [12], by using TRNSYS, simulated an experimental OVF module, indicating that the opaque ventilated façade has potential to achieve free ventilation and air preheating and its performance could largely be dependent on the wind speed and direction, as well as the intensity of solar radiation. Aparicio-Fernández et al. [13] made the combined use of TRNSYS and TRNFlow to simulate the performance of an OVF, and compare the simulation results with experimental data. The study indicated that the collection of the hot air from the façade for the use in the building helped to reduce the building's heat demand. Some authors $[14,15,16,17,18]$ conducted the numerical investigation of the performance of the OVF by comparing it with the same sized unventilated façade (without the air cavity) or sealed façade. The results show that the OVF can achieve more than $40 \%$ energy saving during summer period owing to the reduction in heat gain and ventilation of the air cavity. During winter, some results $[16,17,18]$ show that the OVF is less advantageous mostly for low solar radiation period. When solar radiation is low, the cold air will be sucked into the cavity that will lead to the increased heat losses. However, when solar radiation is higher, the hot air will be gathered at the air cavity that 
leads to the reduced pressure difference between the inside and outside of the building; consequently, the heat loss of the building will be significantly reduced.

In order to improve the efficiency of OVFs, some PCM materials were attached to the external skin of the OVF while some microencapsulated PCM particles were filled into the air cavity. Numerical studies of Diarce et al. [19] indicated that thermal inertia of the PCM incorporated ventilated façade is higher than that of the conventional ventilated facades, while $\mathrm{PCM}$ incorporated $\mathrm{OVF}$ can achieve 0.7 to $2^{\circ} \mathrm{C}$ higher indoor air temperature. Experimental study by Gracia et al. [20,21] showed that filling the macro encapsulated PCM into the cavity can achieve the electrical energy savings by around 19 to $26 \%$ for a full year duration. However, during summer period, energy saving is unachievable owing to excessive use of mechanical ventilation for the complete solidification of the PCM in the air cavity.

At the present, there is still a challenge to widely applying OFVs in different climates and seasons. As highlighted by Ibañez-Puy et al. [10], integration of different technologies (decentralized heating/ cooling units, heat exchangers, energy supply devices, energy storage,...) into OVFs could be a solution to extend its application in diverse climates and seasons. To our knowledge, integration of some technologies such as heat recovery units and energy storage systems into OFVs has not yet been investigated and reported. In order to respond this challenge, a numerical investigation of an innovative OVF that integrates a smart modular heat recovery unit (SMHRU) and a latent heat thermal energy system (LHTES) is proposed. The advantage of the SMHRU integration is to recover the waste energy, thus decreasing heat demand of the building during winter and enhancing quality of the indoor air. During summer, the system allows the fresh air to be delivered when needed, thus reducing the cooling energy demand of the building. In terms of the LHTES, its integration allows the energy to be stored during cold nights and discharged during the daytime period that leads to cooling of the housing. This system using phase change materials takes the advantage of temperature gap between day and night to maintain thermal comfort within the recommended range. Another advantage of the OVF with the SMHRU and LHTES (E2VENT system) is to prevent the use of large duct system that is dedicated to convey the ventilation air throughout the whole building, thus preventing the disruption to building occupants. In this paper, energy performance of the E2VENT system was investigated numerically in order to provide recommendations for its optimum performance. The innovative E2VENT retrofitting strategy 
was compared to an equivalent, traditional retrofitting strategy and its benefits were highlighted.

\section{Description of the innovative E2VENT system}

The system is composed of a SMHRU unit and a LHTES unit; both are integrated into the air cavity of the façade, as shown schematically in Fig. 1. The two units were designed with high flexibility and can be accommodated into the air cavity $[22,23]$.
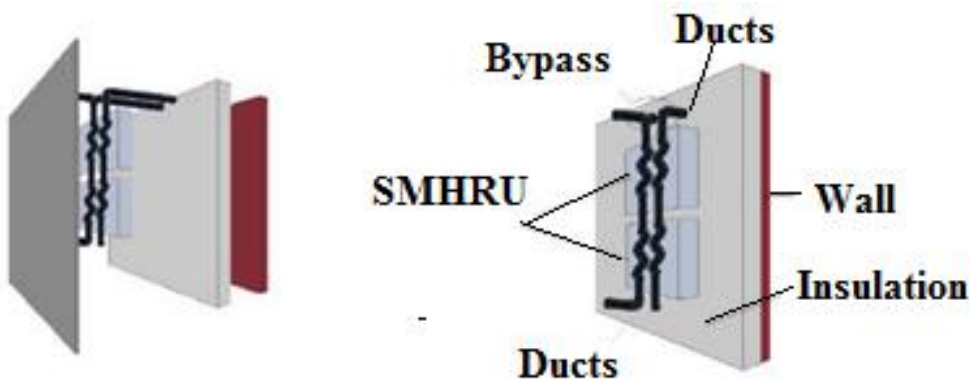

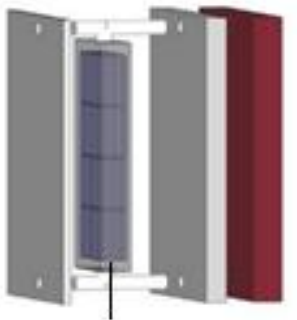

LHTES

Fig. 1: E2VENT concept presentation. Left: E2VENT module. Centre: SMHRU, right: LHTES [23]

Fig. 2 presents the schematic of the SMHRU and LHTES and their integration in the air cavity. The SMHRU is used to recover heat from the ventilation air, i.e., pre-heating the supply air in winter and pre-cooling it during summer.

The LHTES uses dedicated air pipes to connect the indoor to outdoor in order to store and release the heat as required. The casing of the LHTES is made of Etalbond $\odot$ and composed of two panels ( 1 and 5 in Fig. 2b) that can integrate the encapsulated PCM into either tubes or plates (4 in fig 2b). It stores energy during cold nights and discharge it during the daytime in order to cool the associated thermal zone. As shown in Figure 2d, the LHTES runs on three operational modes:

- EXT- EXT: This refers to the charge of the system. Exterior air, extracted from the outside or from the air cavity, is forced through the PCM/air exchanger and then discharged to the outside. In this mode, no. 3 fan is in operation (Fig. 2b).

- INT - INT: This refers to the discharge of the system. During this operation, the indoor air is sucked in, forced through the LHTES (with the heat exchange with PCM), and then delivered back to the inside of the building. In this mode, no. 6 fan is in operation. 
- OFF: No air movement and heat exchange take place in this mode. The system is actually in sleeping mode.

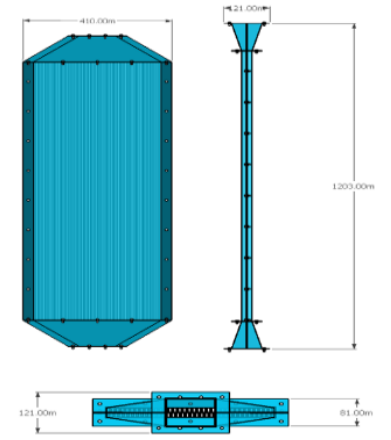

a

SMHRU Design

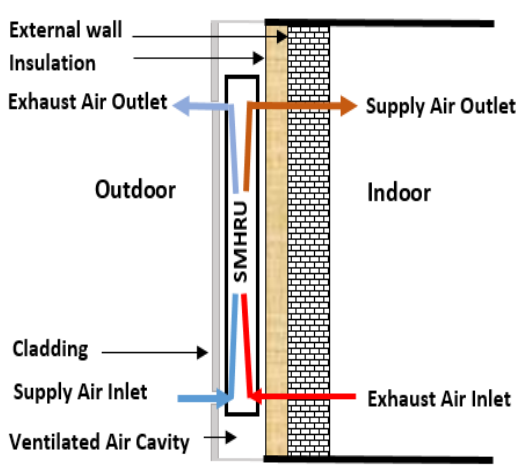

C

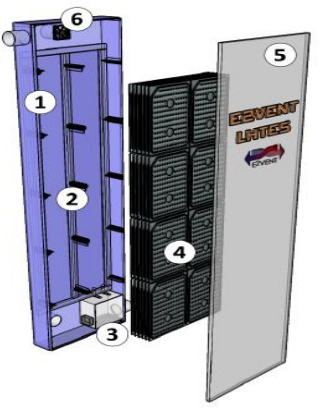

B

LHTES Design [23]
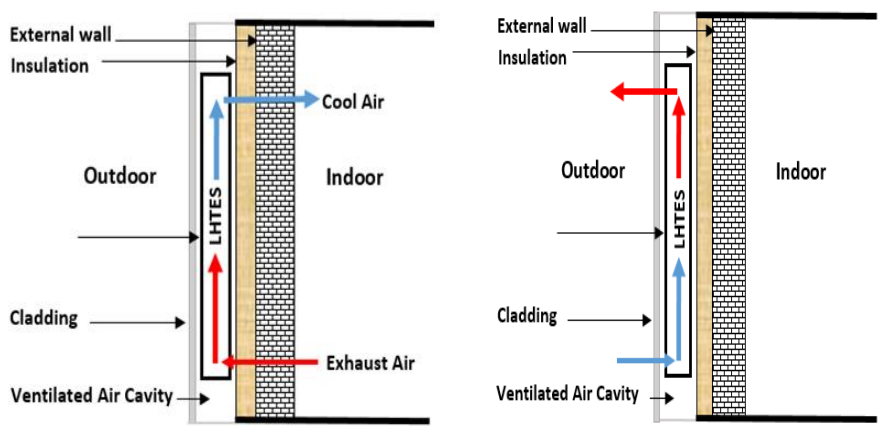

Discharging mode (INT-INT) Charging mode (EXT-EXT)

$\mathrm{D}$

Integration of the SMHRU in the wall Integration of the LHTES in the wall

Fig. 2: a) SMHRU design b) LHTES design c) SMHRU Integration in the wall, d) LHTES Integration in the wall.

\section{Presentation of the E2VENT System model}

The global model was developed to optimise the geometrical settings and predict and optimize energy performance of the E2VENT system. The model was developed by integrating the system's components models in TRNSYS simulation environment. In fact, the model is composed of two parts: one for the building and one for the facade (Fig.3). 


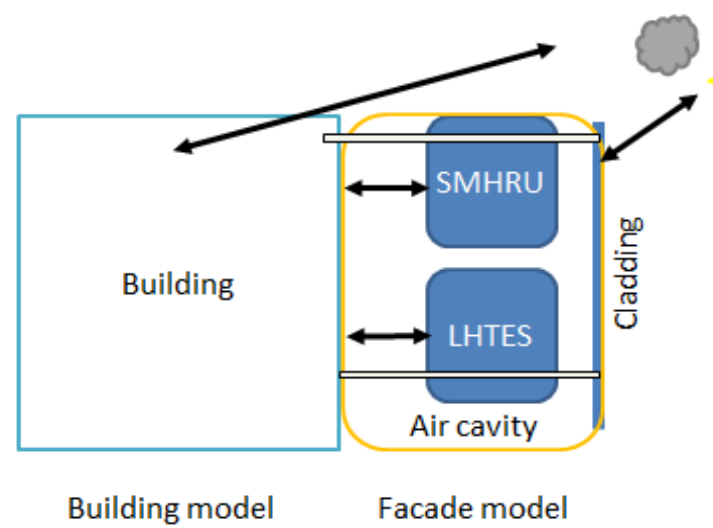

Fig. 3: Building model and facade model

Fig.4 presents the schematic of the system's components. By using the weather data and simulation input data of the building, the heating and cooling loads are estimated. When the facade model, comprising the SMHRU and LHTES sub-models, is coupled with the building model, an integrated model is established and then the impact of the façade on heating and cooling loads can be assessed. The global model operation is controlled by a BEMS, which can control the energy charging and discharging of the LHTES.

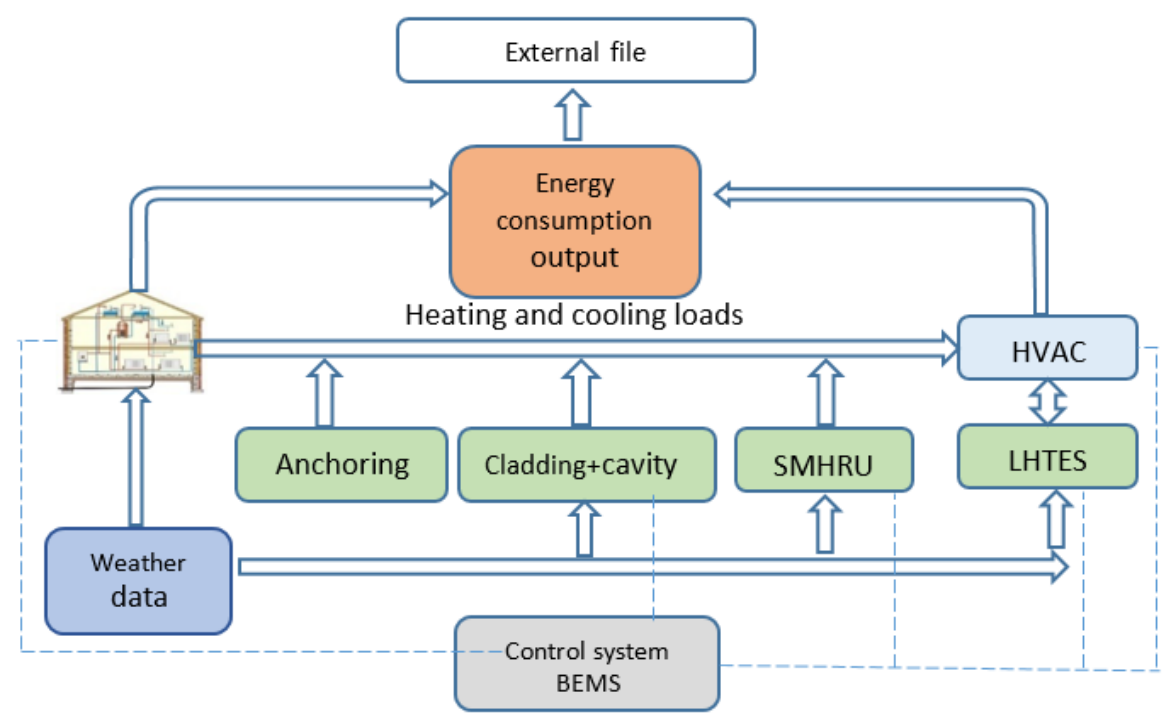

Fig. 4: Schema of the system elements

The following parts present the description of the system components models. 


\section{a. SMHRU Model:}

A simplified empirical model is proposed in order to evaluate the SMHRU performance. This model was developed by using experimental data [22]. The heat transfer between the supply and exhaust airs is given by:

$$
Q=\mathrm{a}_{1}+\mathrm{a}_{2} \cdot \mathrm{q}_{\mathrm{a}}+\mathrm{a}_{3} \cdot \Delta \mathrm{T}+\mathrm{a}_{4} \cdot \mathrm{q}_{\mathrm{a}} \cdot \Delta \mathrm{T}+\mathrm{a}_{5} \cdot \mathrm{q}_{\mathrm{a}}{ }^{2}+\mathrm{a}_{6} \cdot \Delta \mathrm{T}^{2}
$$

Where $\mathrm{a}_{1}=0.5683, \mathrm{a}_{2}=0, \mathrm{a}_{3}=0.3647, \mathrm{a}_{4}=0.3438, \mathrm{a}_{5}=0, \mathrm{a}_{6}=0.001006 . \mathrm{q}_{\mathrm{a}}\left[\mathrm{m}^{3} / \mathrm{s}\right]$ is the volume air flowrate. In this case, the fans' electrical demand is given by:

$$
\mathrm{P}_{\text {elec }}=\mathrm{b}_{1} \cdot\left(\mathrm{q}_{\mathrm{a}}\right)^{\mathrm{b} 2}
$$

Where $b_{1}=0.0052, b_{2}=2.296$.

The outlet temperatures can be calculated according to the selected operational mode (heating and cooling). For heating operation, the exhaust air can be recovered and thus the outlet air temperature is given by:

$$
\mathrm{T}_{\mathrm{in} 2}=\mathrm{T}_{\mathrm{in} 1}-\Delta \mathrm{T}
$$

Where, $\mathrm{T}_{\mathrm{in} 1}$ is the exhaust air temperature. During calculation, same $\Delta \mathrm{T}\left({ }^{\circ} \mathrm{C}\right)$ is considered for both air streams, which have the same mass flow rate.

$$
\Delta \mathrm{T}=\mathrm{Q}_{\text {model }} \mathrm{l}\left(\mathrm{m} \mathrm{Cp}_{\text {air }}\right)
$$

The supply air temperature delivered into the building could be higher, given by:

$$
\mathrm{T}_{\text {out } 2}=\mathrm{T}_{\text {out } 1}+\Delta \mathrm{T}
$$

Where $\mathrm{T}_{\text {out } 1}\left({ }^{\circ} \mathrm{C}\right)$ is the outdoor supply air temperature.

For the cooling mode, the exhaust airstream can be warmer, given by:

$$
\mathrm{T}_{\mathrm{in} 2}=\mathrm{T}_{\mathrm{in} 1}+\Delta \mathrm{T}
$$


When the supply air stream can be cooled, the supply air temperature is given by:

$$
\mathrm{T}_{\text {out } 2}=\mathrm{T}_{\text {out } 1}-\Delta \mathrm{T}
$$

The coefficient of performance (COP) of the SMHRU is expressed as:

$$
\mathrm{COP}=\mathrm{Q} / \mathrm{P}_{\text {elec }}
$$

While the thermal efficiency $\eta$ is expressed as:

$$
\eta=\left|\left(T_{\text {in1 }}-T_{\text {in } 2}\right) /\left(T_{\text {in } 1}-T_{\text {out } 1}\right)\right|
$$

\section{b. LHTES Model}

The LHTES model, based on the study by Rouault et al. [24], was developed for a tube bundle heat exchanger. The temperature of the PCM and its percentage of solid phase are considered homogeneous in the whole LHTES system. Three energy balances are written: on the whole system (that can be seen on Fig. 5), on a horizontal section in the system, on the PCM. Then the air temperature is calculated along the channel and especially the one at the exit. The temperatures of the PCM, especially the one at the exit, are also calculated. Figure 5 presents the heat exchanges of the LHTES system.

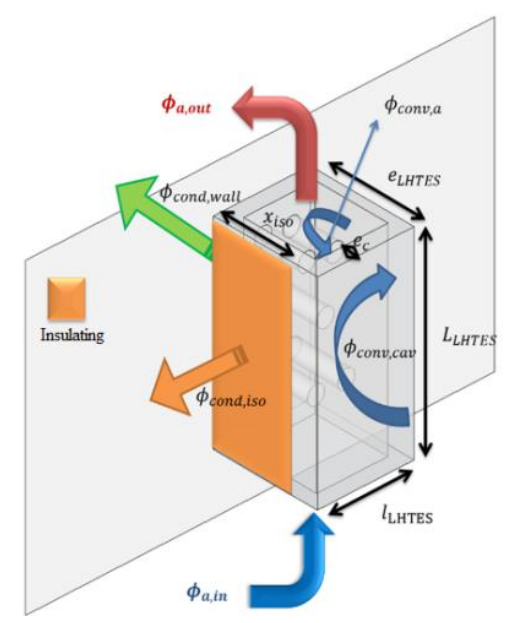

Fig. 5: Heat exchanges of the LHTES 
The equations used refer to a staggered tube heat exchanger but these can be alternated or updated for other heat exchange apparatus. The heat exchanging efficiency is calculated by using the NTU method [25] for a cross-flow heat exchanger in which the secondary fluid (PCM) has a uniform temperature. A global heat loss calculation is included to simulate the slow decrease (or increase) of the PCM temperature during a certain time period, depending upon the given environment conditions. The PCM temperature within the heat exchanger is considered to be identical. At this condition, the calculations are carried out as follow:

\section{Preliminary calculation:}

The outside heat loss surface:

$$
A_{\text {ext }}=2(X \cdot Y+Y \cdot Z+Z \cdot X)
$$

The mean cross sectional area of the air channel: $\quad A_{s}=\left(\mathrm{PX} \cdot \mathrm{Y} \cdot \mathrm{Z}-\mathrm{NY} \cdot l_{t} \cdot \pi \cdot d_{\text {out }}{ }^{2} / 4\right)$

The heat exchange surface area: $\quad \mathrm{A}=\left(\mathrm{NX} \cdot \mathrm{NY} \cdot l_{t} \cdot \pi d_{\text {out }} \cdot\right)$

The maximum air velocity for Reynolds calculation: $v_{\text {air }}=\frac{q_{q}}{3600} \cdot \frac{1}{\left(\mathrm{Y} \cdot \mathrm{Z} \cdot-d_{\text {out }} / \mathrm{PY}\right)}$

The Reynolds number: $R e=\rho_{a} \cdot v_{\text {air }} \cdot d_{\text {out }} / \mu_{a}$

\section{Correlation for the staggered arrangement}

$\mathrm{Fa}=1+0.1 * \frac{\mathrm{PX}}{d_{\text {out }}}+0.34 * \frac{d_{\text {out }}}{\mathrm{PY}}$

The Nusselt number: $\mathrm{Nu}=0.35 \cdot \mathrm{Fa} \cdot \mathrm{Re}^{0.57} \cdot \operatorname{Pr}^{0.31}$

The friction factor: $\quad \mathrm{xi}=0.44\left(\frac{\left(\mathrm{PY}-d_{\text {out }}\right)}{\left(\frac{\mathrm{PY}^{2}}{4}+\mathrm{PX}^{2}\right)^{0.5}-d_{\text {out }}}+1\right)^{2} *\left(\mathrm{Re}^{-0.27}\right) *\left(\frac{\mathrm{X}}{\mathrm{PX}}+1\right)$

\section{Efficiency calculation:}

The convective coefficient: $\quad \mathrm{h}=\lambda \cdot \frac{\mathrm{Nu}}{\Delta \mathrm{T}_{f}}$

The Unit Transfer Number:

$$
\mathrm{NTU}=3600 \cdot \mathrm{h} \cdot \frac{\mathrm{A}}{\left(\rho_{\mathrm{a}} \cdot q_{a} \cdot \mathrm{Cpa}\right)}
$$

The heat exchanger efficiency: $\quad \varepsilon=1-\exp (-\mathrm{NTU})$

The heat power to/from the air during a time step: 
$\frac{\mathrm{dPa}}{\mathrm{dt}}=\varepsilon \cdot \rho_{\mathrm{a}} \cdot \frac{q_{a}}{3600} \cdot \mathrm{Cp}_{a}\left(\mathrm{~T}-T_{m}\right)$

The heat losses through the wall during a time step can be written as:

$\frac{\mathrm{dPhl}}{\mathrm{dt}}=\frac{1}{\mathrm{Rhl}} \cdot\left(T_{\text {in }}+T_{\text {out }}-2 \cdot T_{m}\right)$

The PCM temperature variation over a time step is given by:

$$
\frac{\mathrm{dTm}}{\mathrm{dt}}=\frac{\frac{\mathrm{dPa}}{\mathrm{dt}}+\frac{\mathrm{dPhl}}{\mathrm{dt}}}{\pi \cdot l_{t} \cdot \frac{d_{\text {out }}{ }^{2} \cdot \mathrm{X} \cdot \mathrm{NY}}{4 \cdot \mathrm{PX} \cdot \mathrm{PY}} \cdot \rho_{\mathrm{m}} \cdot\left(C p_{m}+L_{m} \cdot \frac{\mathrm{dS}}{\mathrm{dTm}}\right)}
$$

Where:

$\frac{\mathrm{dS}}{\mathrm{dTm}}=0.5 \cdot \frac{\pi}{\Delta T_{f}} \cdot\left(1-\tanh ^{2}\left(\pi \cdot \frac{\mathrm{Tf}-\mathrm{Tm}}{\Delta T_{f}}\right)\right)$

$\frac{d S}{d T m}$ is the derivative of PCM liquid fraction on PCM temperature. The equation (23) is solved by using the Runge-Kutta 6 Method [26] and yields the PCM temperature of $T_{m}$ for each time step. The control of the LHTES is carried out based on the temperature of the PCM, which can give instant indication to the heat storage level. 


\section{c. BEMS Model}

The BEMS is designed to control the integrated system, their interaction with the HVAC systems of the building, in order to obtain the heat or cold energy necessary to reaching the temperature level as required, thus obtaining the expected thermal comfort [27]. The BEMS was developed with the MATLAB environment. The program is divided into several functional blocks that can operate at different levels, as shown in Fig. 6.

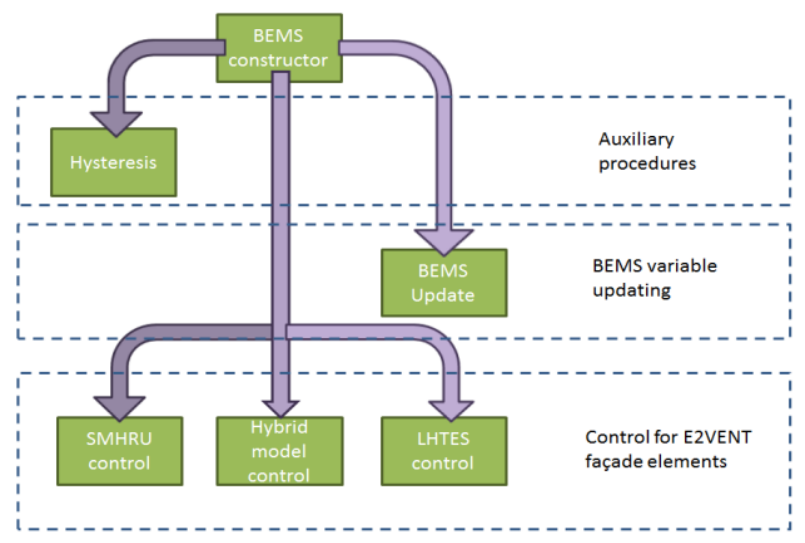

Fig.6: Functions of BEMS code.

The constructor generated the BEMS object that is to be handled by the program (called through the corresponding TYPE in TRNSYS). The functions of the program components can be classified by the entity, as below:

- From the main control of the TRNSYS, the updated procedure is invoked to get the new values of the system.

- The elements of the façade have to send some outputs to the corresponding model control in the BEMS. For example, the outputs from the LHTES should invoke the outputs from the BEMS.LHTES.

- The auxiliary procedures (in this case only the hysteresis element) are used inside the BEMS so they are called internally.

Considering the usage of the standard TYPE 155 coupling TRNSYS and Matlab, the correct way to run the model is to invoke the BEMS to create the BEMS object, and then call the 
corresponding function as previously addressed. The following section presents different functions of the system.

Hysteresis function: The idea behind this function is to avoid unstable situations when the system is near to reaching the goal value. This is not just useful to surpass spurious error control inputs (notice, just error singularities, other like rebounds in buttons won't be properly solved), but also avoid to constantly switch the devices on and off when the global system fluctuates around the goal value. The schematic of the global model is shown in Fig. 7.

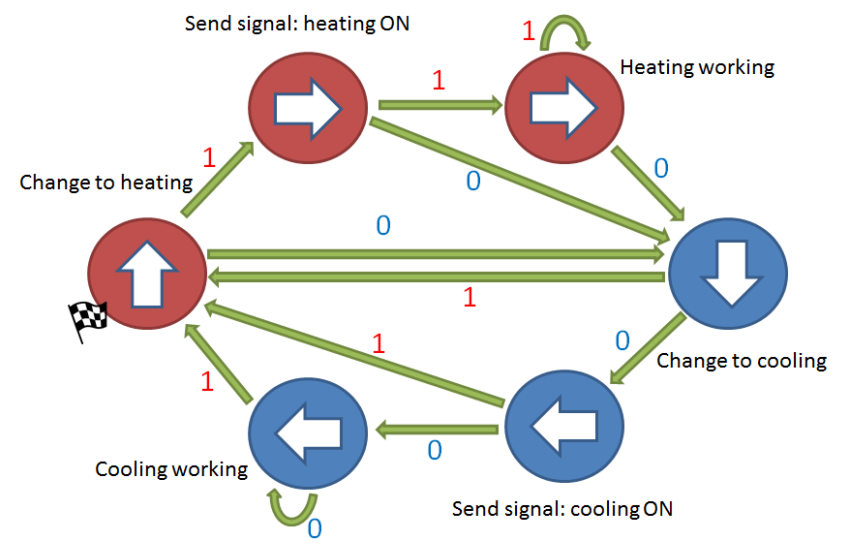

Fig. 7: Hysteresis process for heating/cooling signals.

The flag represents the initial status by default. The 1's and 0's mean that the system needs to apply heat (temperature of the room is below the goal temperature) for 1's or needs to cool the building (temperature of the room is over the goal temperature) for 0 's. It should be noted that two heating signals are needed to determine whether or not switching on the heating mode. Similarly, the two cooling signals are needed for determination on whether or not switching on the cooling mode.

Update function: The following steps are proposed to enable updating the function of the model

- Selecting the action to be taken: By using the comparison shown in Table 1 which gives the reference temperatures, the result shows a way that the system should apply to reach the goal, an appropriate action is selected to allow us to know "what" to do, rather than "how" to do.

- Determining the hysteresis factor (see below) for processing the next action. 
- Delivering the output values. In the first version, a generic fan is considered to be attached to each LHTES and SMHRU to simulate the flux of air in terms of all/nothing. Moreover, the HVAC is modified (use it for cooling or heating, or deactivate it) considering that it can be used in various modes that could influence the results in an unknown way (at least in measurable terms).

- Storing the values of the temperatures and other parameters for the next iteration or as the final outputs to be used by controlling elements of the façade.

Hybrid function: This function is designed to cover the case in which the LHTES and the SMHRU were designed as a single entity, sharing ducts and valves, and possibly fans. The logic behind the function gives the priority to the air refreshment over the heat interchange. In fact, the function accepted a signal named "Renovation_RQ" that gives the priority to air refreshment for switching on/off the valves in the hybrid system. Otherwise, different modes are developed based on the temperature reference values given below:

\begin{tabular}{|l|l|l|l|l|}
\hline Tgoal $>$ Troom & Tpcm $>$ Troom & Discharge "heat" & \\
\hline & Else & Tpcm<Toutdoors & Charge "heat" & \\
\hline & Else & Toutdoors $>$ Troom & "Free heating" \\
\hline Else & Tpcm<Troom & Discharge "cool" & Idle \\
\hline & Else & Tpcm>Toutdoors & Charge "cool" & \\
\hline & Else & Toutdoors $<$ Troom & "Free cooling" \\
\hline & & Else & Idle \\
\hline
\end{tabular}

Table 1: Logic for the hybrid model

Charge and discharge are the processes relating to the PCM and its energy storage capability. The "free" status happens when the external temperature can help reach the goal temperature, while 'idle' status indicates that the system is not in working condition. For example, if one needs to heat the room, while the PCM has no heat stored inside or is unable to store heat, or the outdoor air temperature is lower than the room temperature, the system ceases to do anything. In this case, the HVAC of the building is activated. The return values of the 
function are the status of the valves that is the control measure of the system in TRNSYS, which takes 0 as 'OFF' and 1 as 'ON'.

LHTES control function: The LHTES control function works at the almost same way as to the hybrid model works when the renovation parameter "Renovation_RQ" is in 'off' state. The only difference is the outputs given by the function. Instead of giving the valves' values, it returns with a status value of "discharge", "charge", "free" or "idle" that work at a similar way as it is stated in the hybrid model. In this way, the LHTES module is forced to "know" what these control words mean, and inside the black box of the LHTES there should be a module to translate these words into control commands, e.g., to open/close valves, and/or to activate/deactivate fans. It is obvious that this part can be moved from the LHTES module to the BEMS module directly in the forthcoming evolutions of the system.

SMHRU control function: The SMHRU function is the simplest procedure for all façade device controls. It has to be gathered to activate the air renovation through the input "Renovation_RQ", and resends it with no further process. One possible evolution for this function is to evaluate if the air renovation is necessary when no request signal has been provided. To achieve this, there should be something to previously simulate the effect of $\mathrm{CO}_{2}$ generation inside the building, and then the BEMS should receive the level of $\mathrm{CO}_{2}$ and decide whether or not it is reasonable to activate the SMHRU considering some relevant factors, e.g., time of the day, acceptable level of $\mathrm{CO}_{2}$, energy usage etc.

\section{d. Integration of the system models in TRNSYS}

This section presents the integration of the E2VENT models in the Building Energy Performance Simulation Tool TRNSYS. The system contains five main components: HVAC system (solid blue lines), air cavity (solid pink lines), SMHRU (Solid red lines), LHTES (Solid green lines), BEMS (mauve and black lines), and anchoring system (included in the Type 56 as thermal bridges). The combination algorithms of these components are shown in Figs. 8 and 9. During integration, the temperature rate control method was used. 


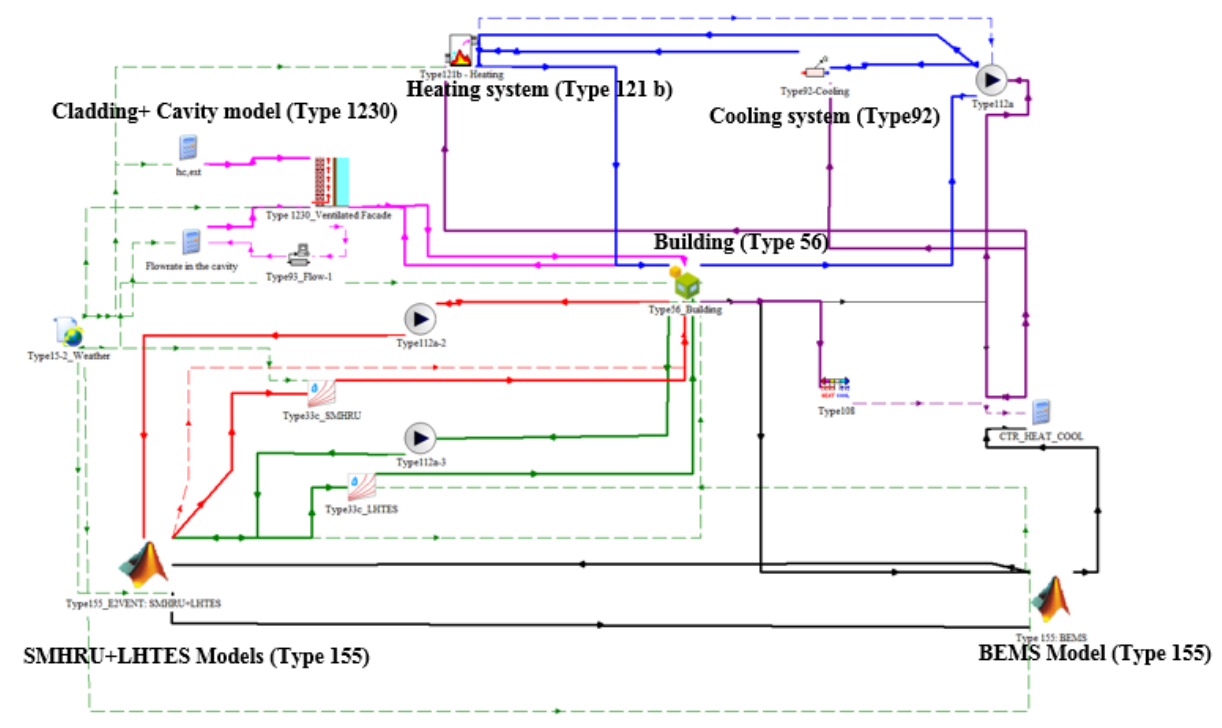

Fig.8: Architecture of the global model, connection of the building with the HVAC system, SMHRU, LHTES, Air Cavity, and BEMS

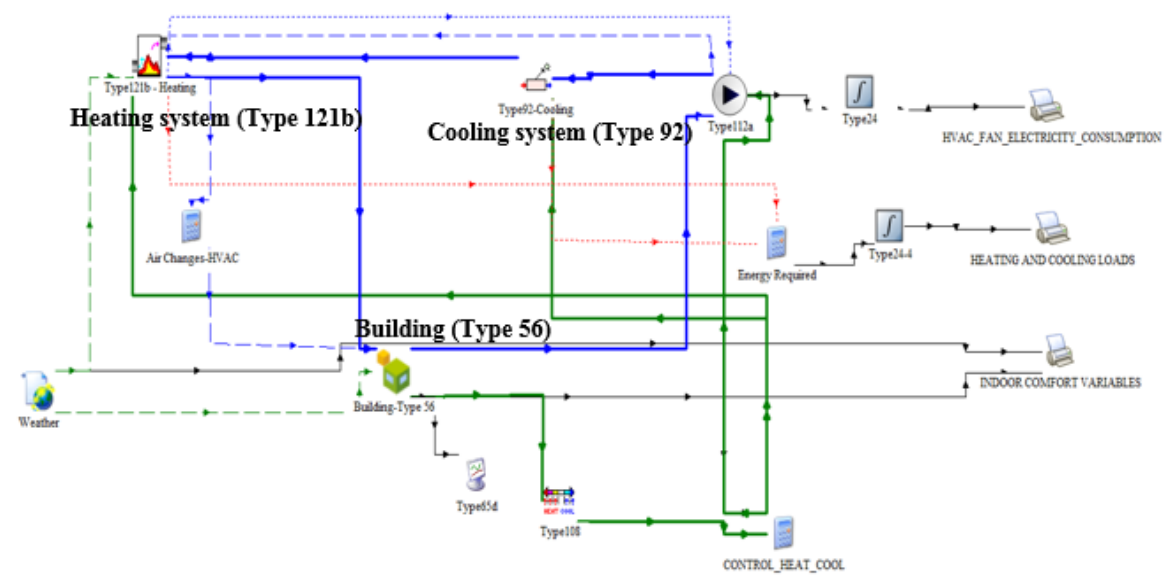

Fig. 9: Architecture of the reference model, connection of the building with the HVAC system

\section{i. Connection of HVAC system with the building model}

The HVAC system of the building is connected with the building zone (type 56), while the multi-zone building model (type 56) is associated with an air node to each building zone. Two types of TRNSYS are used to represent the heating and cooling devices, i.e., the air heater device type $121 \mathrm{~b}$ for heating and the air cooler device type $92 \mathrm{~b}$ for cooling [28]. For each time step, the heating and cooling devices give the energy required to heat and cool the building and the electricity consumption of the fan. 


\section{ii. Integration of the Air Cavity model}

The thermal behaviour of the cavity is simulated by coupling the thermal building zone (Type 56) into Type 1230 [29], while the Type 1230 is functioned to simulate an exterior wall which has an indefinite exterior surface and a ventilated air gap behind. The back side of the air gap has a small resistive layer, whose temperature and thermal resistance are linked to the Type 56 wall for simulation of the heat transfer across the interior wall. In overall, the model covers the following items: (1) absorption of solar radiation on the exterior surface; (2) long-wave radiation exchange with the sky from the exterior surface; (3) convection to the ambient air; (4) energy storage in the massive wall; (5) conduction through the wall; (6) radiation exchange through the air gap; (7) convective exchanges to the air stream from both air gap surfaces and conduction through the resistive layer (insulation). In the Type 1230, the air mass flow rate is constant. To simulate the evolution of the mass flow rate within the cavity, a simple model developed by Grau and Rode [30] is used. The airflow in the cavity is driven by natural forces, by the effect of the wind and the stack effect.

\section{iii. Cladding Integration and system anchoring}

Since thermal bridges in ventilated facades are an important parameter of their thermal performance, within the framework of the E2VENT project, a multi-parametric tool for their accurate calculation has been developed [31, 32]. The tool is based on EN ISO 10211 [33] and it provides accurate point thermal bridge results that can be then implemented in the TRNSYS simulation using the equivalent wall method described in [34]. In order to take into account heat flow through thermal bridges, detailed characteristics of the structural system are required in order to describe the geometry and materials of each specific anchor. The tool, specially developed for the needs of this calculation, provides all necessary information to allow the implementation of heat flow through thermal bridges in the TRNSYS simulation.

\section{iv. Integration of the SMHRU model in TRNSYS:}

The SMHRU system is simulated in the TRNSYS by using the type 155 that can call for the outcomes of the Matlab model. The system has two airstreams (Fig. 10), one for the supply air and the second for the exhaust air. For each time step, two heat mass fluxes $Q_{\text {supply }}$ and $\mathrm{Q}_{\text {exhaust }}$ are added into the convective heat flux balance equation. 


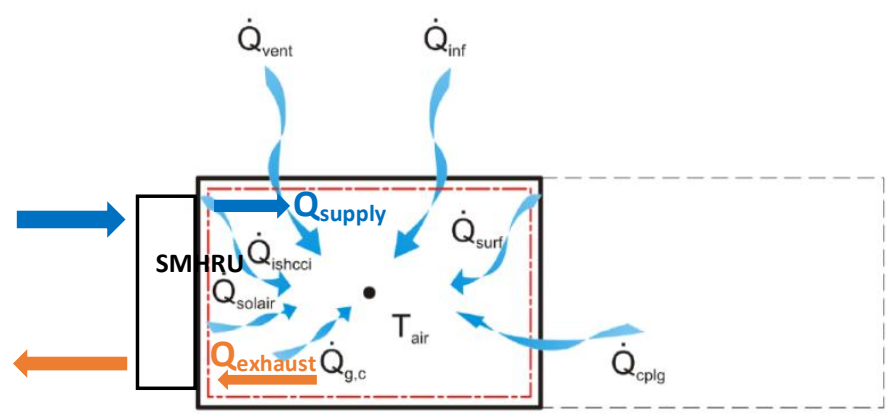

Fig. 10: Heat balance on the air node, adapted from [28]

The convective heat at a single node is given by:

$Q_{\mathrm{i}}=Q_{\text {surf }, \mathrm{i}}+Q_{\mathrm{inf}, \mathrm{i}}+\mathrm{Q}_{\mathrm{vent}, \mathrm{i}}+\mathrm{Q}_{\mathrm{g}, \mathrm{c}, \mathrm{i}}+\mathrm{Q}_{\mathrm{cplg}, \mathrm{i}}+\mathrm{Q}_{\text {solar }, \mathrm{i}}+\mathrm{Q}_{\mathrm{ISHCCI,i}}+\mathbf{Q}_{\text {supply }}-Q_{\text {exhaust }}$

Where:

$Q_{\text {supply }, i}=q_{v} \rho c_{p}\left(T_{\text {out } 2, i}-T_{\text {air }, i}\right)$

As the heat gain resulted from the moisture gain due to the SMHRU is added to the moisture balance equation of the zone. The moisture gain is given by:

$M_{\text {supply }, i}=q_{v} \rho c_{p}\left(w_{\text {out } 2, i}-w_{\text {air }}\right)$

\section{v. Integration of the LHTES model in TRNSYS:}

As the LHTES system is simulated in TRNSYS involving a calling for Matlab using the type 155, the system has two airstreams (Fig. 11), i.e., one airstream within the building zone and the other outside the building. The airstream within the building zone is linked to the Type 56 . For each time step, two convective heat fluxes $\mathrm{Q}_{\text {supply }}$ and $\mathrm{Q}_{\text {exhaust }}$ are added into the heat balance equation. 


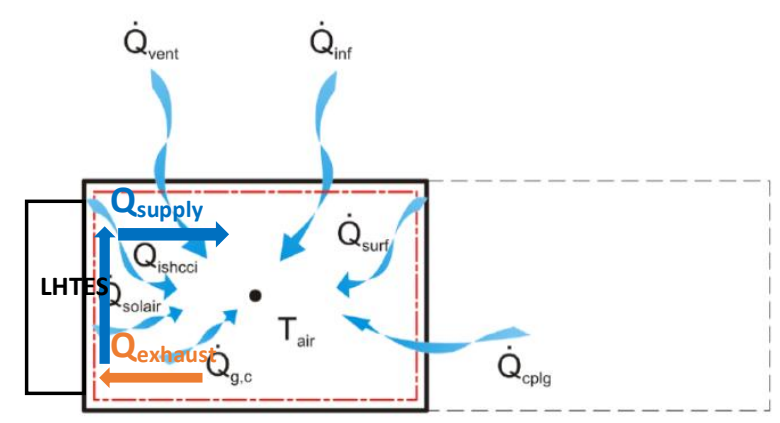

Fig. 11: Heat balance on the air node, adapted from [28]

The convective heat at a single node is given by:

$\mathrm{Q}_{\mathrm{i}}=\mathrm{Q}_{\text {surf }, \mathrm{i}}+\mathrm{Q}_{\mathrm{inf}, \mathrm{i}}+\mathrm{Q}_{\mathrm{vent, \textrm {i }}}+\mathrm{Q}_{\mathrm{g}, \mathrm{c}, \mathrm{i}}+\mathrm{Q}_{\mathrm{cplg}, \mathrm{i}}+\mathrm{Q}_{\text {solar }, \mathrm{i}}+\mathrm{Q}_{\text {ISHCCI,i}}+\mathbf{Q}_{\text {supply }}-\mathbf{Q}_{\text {exhaust }}$

Where, $\mathrm{Q}_{\text {supply }}$ is the mass flux of supply air of the SMHRU

$\mathrm{Q}_{\text {supply,i }}=q_{a} \rho \mathrm{c}_{\mathrm{p}}\left(\mathrm{T}_{\mathrm{m}, \mathrm{i}}-\mathrm{T}_{\mathrm{air}, \mathrm{i}}\right)$

$\mathrm{T}_{\mathrm{m}, \mathrm{i}}$ is equal to the PCM temperature from the LHTES model at each time step.

Moisture gain: As the heat gain resulted from the moisture gain due to the SMHRU is added to the moisture balance equation of the zone. The moisture gain is given by:

$\mathrm{M}_{\text {supply,i }}=q_{v} \rho_{a} \mathrm{c}_{\mathrm{pa}}\left(\mathrm{w}_{\mathrm{m}, \mathrm{i}}-\mathrm{w}_{\mathrm{air}, \mathrm{i}}\right)$

\section{vi. Integration of the BEMS in TRNSYS}

The BEMS is implemented in Matlab and linked to the building zone and HVAC systems via the type 155 for Matlab calling. Fig. 12 presents the connection between the BEMS and different components. At each time step, the BEMS receives a few inputs, including the outdoor temperature, the outdoor temperature, the temperature to reach inside the building, and the actual usage of HVAC systems. Based on these inputs, the BEMS instructs the actions of the SMHRU, LHTES and HVAC, as follows:

- Fan_SMHRU_OUT: Command to send to the SMHRU. 1 (ON) or 0 (OFF)

- Fan_LHTES_OUT: Command to send to the SMHRU. 1 (ON) or 0 (OFF 
- HVAC_OUT: Send command to HVAC. +1 (Heating), 0 (OFF), -1 (Cooling). (If cooling is on, heating is off and vice versa)

- SMHRU_comand: Command to send to the SMHRU. 1 (ON) or 0 (OFF)

- LHTES_coomand: Command to send to the SMHRU. $1(\mathrm{ON})$ or $0(\mathrm{OFF})$

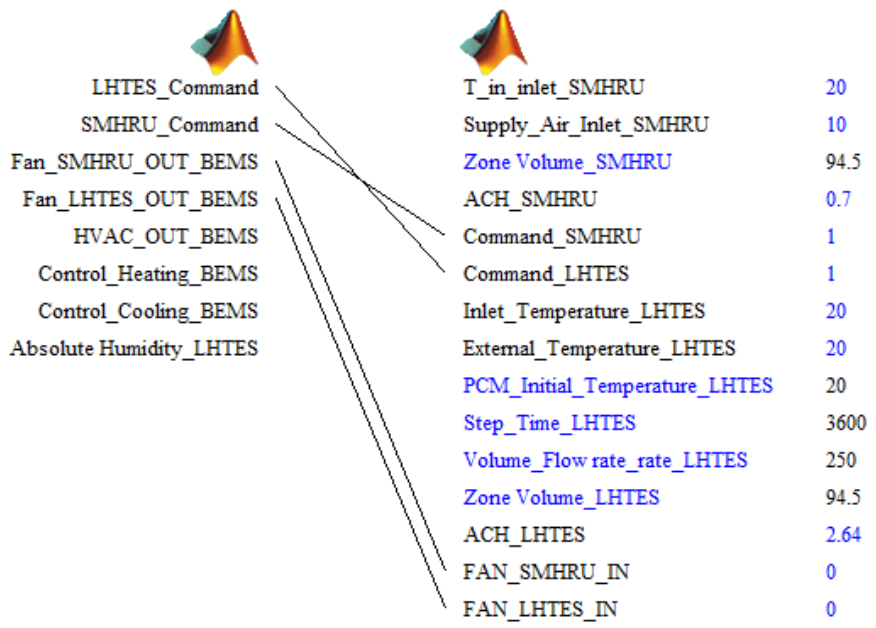

Fig. 12: Connection between the BEMS (Type 155),

LHTES and SMHRU (155).

\section{e. Resolution of the global model}

At each time step, the TRNSYS solver runs repeatedly on all types of simulation (building model and facade model, SMHRU and LHTES) until the convergence in all the outputs is achieved. This ensures the convergence of coupling variables (heat fluxes and air node temperatures) and verification of the boundary conditions. As soon as the calculation is converged, it will be possible to assess the evolution of the all air nodes' temperature, heat fluxes and consequently the energy efficiency of each subsystem, the thermal comfort performance and the building energy consumption.

\section{Quantification of the energy performance of E2VENT system}

The energy efficiency of the E2VENT system $\varepsilon_{E 2 V E N T}$ will be quantified by its ability to decrease HVAC energy consumption. This energy efficiency is expressed as:

$$
\varepsilon_{\mathrm{E} 2 \mathrm{VENT}}=\frac{\mathrm{E}_{\mathrm{ref,p}}-\mathrm{E}_{\mathrm{E} 2 \mathrm{VENT}, \mathrm{p}}}{\mathrm{E}_{\mathrm{ref}, \mathrm{p}}}
$$


The primary energy $E_{\mathrm{E} 2 \mathrm{VENT}, \mathrm{p}}$ consumed by the building with the E2VENT system can be expressed as:

$E_{\text {E2VENT,p }}=E_{\text {heating,p }}+E_{\text {cooling,p }}+E_{\text {hvacfan }, \mathrm{p}}+E_{\text {smhru,p }}+E_{\text {lhtes }, \mathrm{p}}$

Then, the primary energy $E_{r e f, p}$ consumed by the reference building (without the E2VENT system) can be expressed as:

$E_{\text {ref,p }}=E_{\text {heating ref,p }}+E_{\text {cooling ref,p }}+E_{\text {hvacfan ref,p }}$

\section{Presentation of the case study}

In order to test the behaviour of the implemented models, a case study has been fixed. The study consists on a simple rectangular building (Fig. 13a).

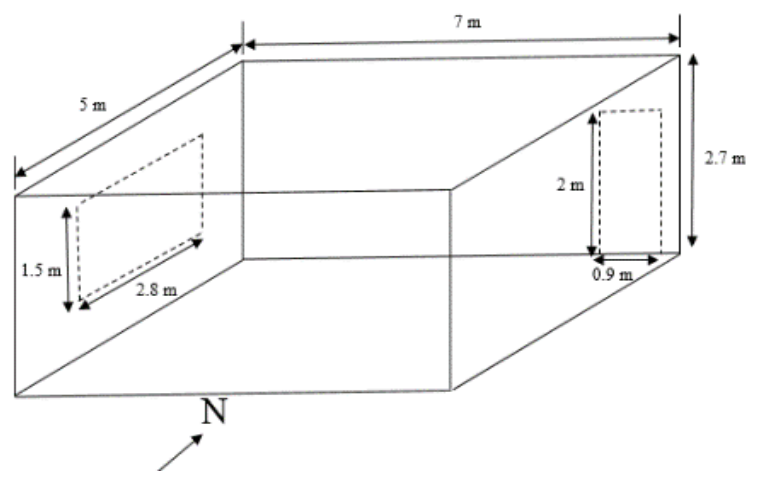

a

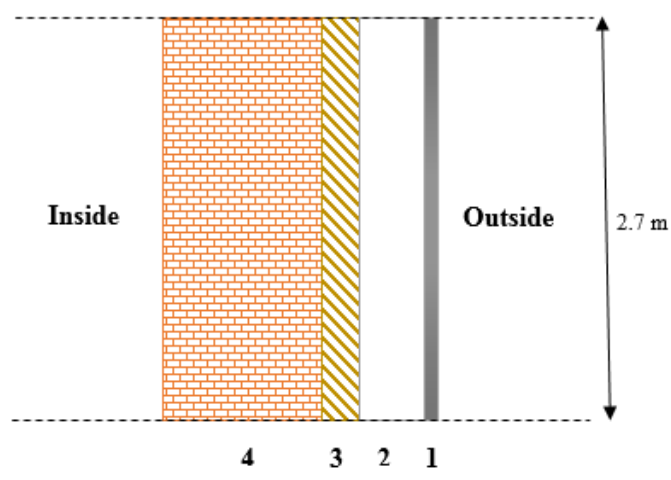

b

Fig. 13: a) Dimensions of the building Study case b) the different layers of the ventilated façade

This first case study focused on energy efficiency of the E2VENT devices: the SMHRU and LHTES. This E2VENT module (SMHRU, LHTES, and Air cavity, Cladding + Anchoring) was installed on the north face for the purpose of assessing its impact on the heating and cooling loads. Table 2 presents the thermal properties of the different layers of the façade. 


\begin{tabular}{|c|c|c|c|c|c|}
\hline Layer & Material & $\begin{array}{c}\text { Thickness } \\
(\mathbf{m})\end{array}$ & $\begin{array}{c}\text { Density } \\
\left(\mathbf{k g} / \mathbf{m}^{\mathbf{3}}\right)\end{array}$ & $\begin{array}{c}\text { Thermal } \\
\mathbf{c o n d u c t i v i t y ~} \\
(\mathbf{W} / \mathbf{m} / \mathbf{K})\end{array}$ & $\begin{array}{c}\text { Thermal capacity } \\
(\mathbf{J} / \mathbf{k g} / \mathbf{K})\end{array}$ \\
\hline $\mathbf{1}$ & $\begin{array}{c}\text { Cladding } \\
\text { (Aluminium) }\end{array}$ & 0.006 & 2700 & 215 & 880 \\
\hline $\mathbf{2}$ & Air gap & 0.04 & - & - & - \\
\hline $\mathbf{3}$ & $\begin{array}{c}\text { Insulation } \\
\text { (Mineral wool) }\end{array}$ & 0.15 & 55 & 0.035 & 1030 \\
\hline $\mathbf{4}$ & Concrete & 0.2 & 2400 & 2 & 1000 \\
\hline
\end{tabular}

Table 2: Thermal properties of the Façade materials.

The building envelope characteristics and the design conditions of the systems are summarized in in Table 3.

\begin{tabular}{|c|c|c|}
\hline Parameters & Reference building & Building with E2VENT \\
\hline $\begin{array}{l}\text { Wall, roof, and floor } \\
\text { characteristics }\end{array}$ & \multicolumn{2}{|c|}{$\begin{array}{c}\text { Uvalue outside wall }=0.9 \mathrm{~W} / \mathrm{m}^{2} / \mathrm{K} \\
\text { Uvalue Roof }=0.5 \mathrm{~W} / \mathrm{m}^{2} / \mathrm{K} \\
\text { Uvalue Ground }=0.5 \mathrm{~W} / \mathrm{m}^{2} / \mathrm{K}\end{array}$} \\
\hline Insulation level & -No Insulation & $\begin{array}{l}\text {-Insulation of the ventilated } \\
\text { façade }(\S \text { Table } 2) \text { on north side. }\end{array}$ \\
\hline Infiltration rate & \multicolumn{2}{|c|}{$1 \mathrm{~h}^{-1}$ (Value Convenient with EN 13779 [35] ) } \\
\hline $\begin{array}{l}\text { Glass and door } \\
\text { properties }\end{array}$ & \multicolumn{2}{|c|}{ Window U_value $=1.4 \mathrm{~W} / \mathrm{m}^{2} / \mathrm{K}$; Door U_value $=0.9 \mathrm{~W} / \mathrm{m}^{2} / \mathrm{K}$} \\
\hline Infiltration rate & \multicolumn{2}{|r|}{$1 \mathrm{~h}^{-1}$} \\
\hline $\begin{array}{l}\text { Type of HVAC } \\
\text { systems }\end{array}$ & $\begin{array}{l}\text {-Air cooler }(121 \mathrm{~b}) \\
\text {-Air heater }(92 \mathrm{~b}) \\
\text {-SMHRU Heat recovery } \\
\text { ventilation (Occupied: } 0.7 \\
\text { Vol/h, Unoccupied: } 0.2) .\end{array}$ & $\begin{array}{l}\text {-SMHRU Heat recovery } \\
\text { ventilation (Occupied: } 0.7 \mathrm{Vol} / \mathrm{h} \text {, } \\
\text { Unoccupied: } 0.2 \text { ). } \\
\text {-LHTES Cooling system } \\
\text { (nominal air flow rate of } 250 \\
\mathrm{~m}^{3} / \mathrm{h} \text {, corresponding to } 2.61 \mathrm{ACH} \text { ) } \\
\text {-Air cooler }(121 \mathrm{~b} \text { ) } \\
\text {-Air heater }(92 \mathrm{~b} \text { ) }\end{array}$ \\
\hline $\begin{array}{l}\text { Lighting system and } \\
\text { lighting control }\end{array}$ & \multicolumn{2}{|c|}{$\begin{array}{c}\text { Lighting: } 10 \mathrm{~W} / \mathrm{m}^{2} \text {, functioning during occupancy (ON/OFF } \\
\text { Control) }\end{array}$} \\
\hline HVAC Control & $\begin{array}{c}\text { Functioning during } \\
\text { occupancy (ON/OFF) }\end{array}$ & BEMS $(\S 2.31)$ \\
\hline Occupancy & \multicolumn{2}{|c|}{3 persons } \\
\hline Equipment & \multicolumn{2}{|c|}{ Equipment: $230 \mathrm{~W} /$ person } \\
\hline $\begin{array}{lr}\text { Building } & \text { and } \\
\text { equipment } & \text { operating } \\
\text { hours } & \\
\end{array}$ & \multicolumn{2}{|c|}{$\begin{array}{l}\text { Weekdays: } 8 \text { a.m-6 p.m; Weekend: no operation (Office } \\
\text { operation) }\end{array}$} \\
\hline Temperature settings: & \multicolumn{2}{|c|}{$\begin{array}{l}\text { Heating set-point: } 26{ }^{\circ} \mathrm{C} \text {; Cooling set-point: } 21{ }^{\circ} \mathrm{C} \text {; Dead-band: } \\
1{ }^{\circ} \mathrm{C} \text {. }\end{array}$} \\
\hline
\end{tabular}

Table 3: Building characteristics and design conditions. 
The same types of HVAC systems (Air heater Type $121 \mathrm{~b}$ and Air cooler $92 \mathrm{~b}$ ) are used for the two cases. For the SMHRU, the bypass is added by considering the cooling set point and the outside temperature. During summer, if the indoor temperature exceeds the cooling set point (Tin> $\mathrm{T}_{\text {setpoint }}$ ) and if the outside temperature is between $18{ }^{\circ} \mathrm{C}$ and the indoor air $\left(18^{\circ} \mathrm{C}<\mathrm{T}_{\text {outdoors }}<\mathrm{Tin}\right.$ ), the supply air is directly blown into the room without passing through the heat exchanger (bypass). By this way, the supply air overheating can be avoided. Regarding the LHTES, it operates at the nominal air flow rate of $250 \mathrm{~m}^{3} / \mathrm{h}$, corresponding to 2.61 ACH. The input parameters of the LHTES model are presented in Table 4.

\begin{tabular}{|c|c|c|}
\hline \multicolumn{2}{|c|}{ Input Material characteristics } & \multirow{2}{*}{$\begin{array}{c}\text { Value } \\
770\end{array}$} \\
\hline$\rho_{\mathrm{m}}$ & PCM density when liquid $[\mathrm{kg} / \mathrm{m} 3]$ & \\
\hline $\mathrm{Cp}_{\mathrm{m}}$ & PCM thermal capacity $\left[\mathrm{J} / \mathrm{kg} /{ }^{\circ} \mathrm{C}\right]$ & 2000 \\
\hline $\mathrm{Lm}$ & PCM latent heat of fusion / solidification $[\mathrm{J} / \mathrm{kg}]$ & 218000 \\
\hline Tf & PCM mean temperature of fusion / solidification $\left[{ }^{\circ} \mathrm{C}\right]$ & 24 \\
\hline DTf & PCM temperature range of fusion / solidification $\left[{ }^{\circ} \mathrm{C}\right]$ & 4 \\
\hline$\rho_{\mathrm{a}}$ & Air density $[\mathrm{kg} / \mathrm{m} 3]$ & 1.20 \\
\hline Cpa & Air thermal capacity $\left[\mathrm{J} / \mathrm{kg} /{ }^{\circ} \mathrm{C}\right]$ & 1004 \\
\hline$\mu_{\mathrm{a}}$ & Air dynamic viscosity [Pa.s] & $1.85 \mathrm{e}-5$ \\
\hline$\lambda$ & Air conductivity $\left[\mathrm{W} / \mathrm{m} /{ }^{\circ} \mathrm{C}\right]$ & 0.026 \\
\hline \multicolumn{3}{|c|}{ Input Fan \& air ducts characteristics } \\
\hline $\mathrm{Rm}$ & Fan mechanical efficiency [-] & 0.75 \\
\hline $\operatorname{Re}$ & Fan electrical efficiency [-] & 0.84 \\
\hline Phi & Fan electrical engine $\operatorname{Cos}(\phi)[-]$ & 0.83 \\
\hline $\mathrm{D}$ & Air duct diameter $[\mathrm{m}]$ & 0.15 \\
\hline marge & Static pressure loss marge $[-]$ & 2 \\
\hline \multicolumn{3}{|c|}{ Input Geometrical parameters } \\
\hline $\mathrm{X}$ & Heat exchanger height $[\mathrm{m}]$ & 2 \\
\hline $\mathrm{Y}$ & Heat exchanger depth $[\mathrm{m}]$ & 0.136 \\
\hline $\mathrm{Z}$ & Heat exchanger width $[\mathrm{m}]$ & 0.8 \\
\hline $\mathrm{d}_{\text {out }}$ & Tube outside diameter $[\mathrm{m}]$ & 0.025 \\
\hline $\mathrm{d}_{\text {int }}$ & Tube inside diameter $[\mathrm{m}]$ & 0.023 \\
\hline$l_{t}$ & Tube length $[\mathrm{m}]$ & 0.8 \\
\hline PX & Longitudinal pitch between two rows [m] & 0.025 \\
\hline PY & Transversal pitch between two tubes [m] & 0.034 \\
\hline
\end{tabular}




\begin{tabular}{|l|l|c|}
\hline Rhl & $\begin{array}{l}\text { Heat losses resistance used for heat losses calculations } \\
{\left[{ }^{\circ} \mathrm{C} / \mathrm{W}\right]}\end{array}$ & 0.6 \\
\hline
\end{tabular}

Table 4: LHTES input parameters

\section{Results and Discussions}

\section{a. Thermal comfort level estimation for different climates}

The efficiency of the E2VENT system was studied for five different climates: humid continental climate represented by Stockholm, Sweden; temperate continental climate represented by Gdansk, Poland; temperate oceanic climate represented by Paris, France; cold semi-arid climate represented by Madrid, Spain; and warm Mediterranean climate represented by Athens, Greece. The first step of the study was to assess the capacity of the system to improve the temperature and relative humidity levels of the building.

Table 5 shows the indoor temperature levels for the two selected days: winter (1 January) and summer (1 August). For all climatic zones, the E2VENT system can significantly improve the indoor temperature level, making it close to the set point temperature of $21^{\circ} \mathrm{C}$, while indoor relative humidity is also closer to the comfort zone, especially in warmer climates, e.g., Athens and Madrid (Table 5).

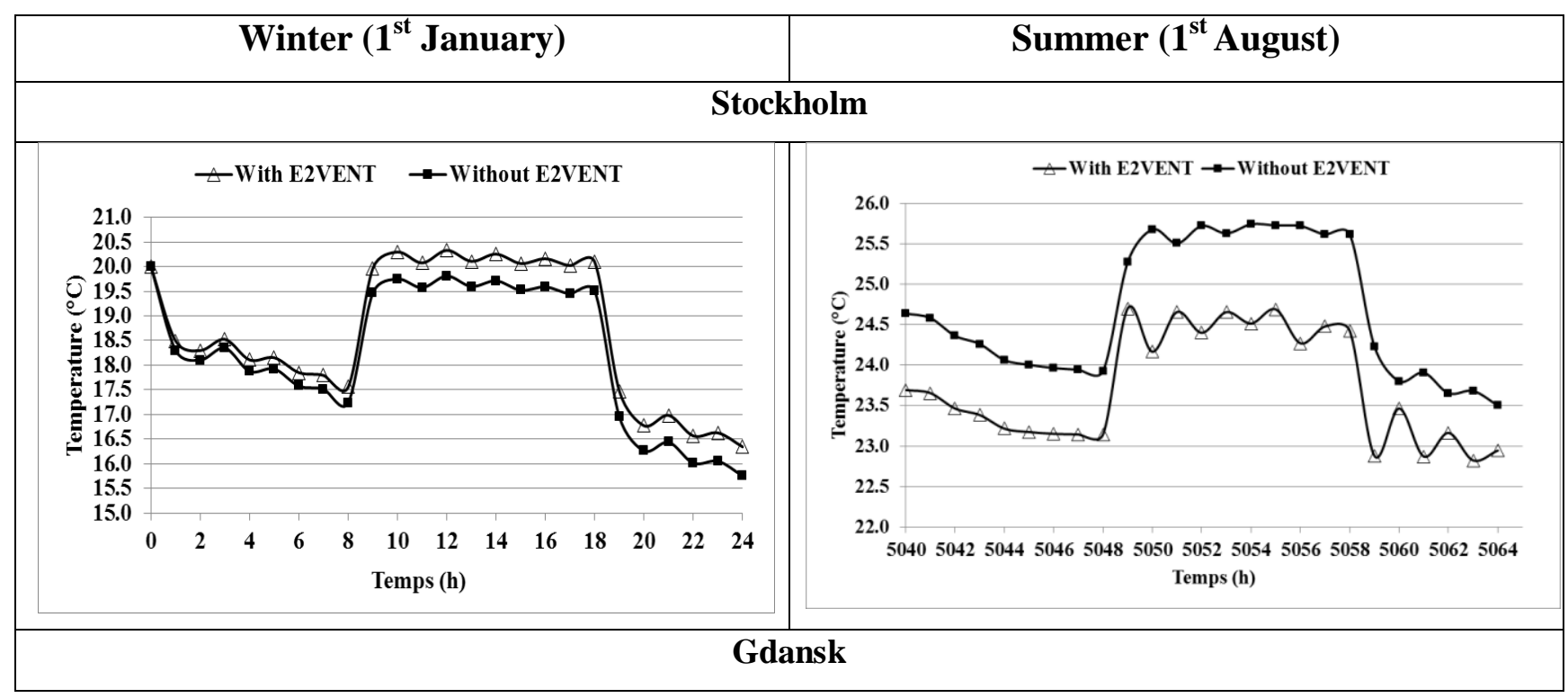




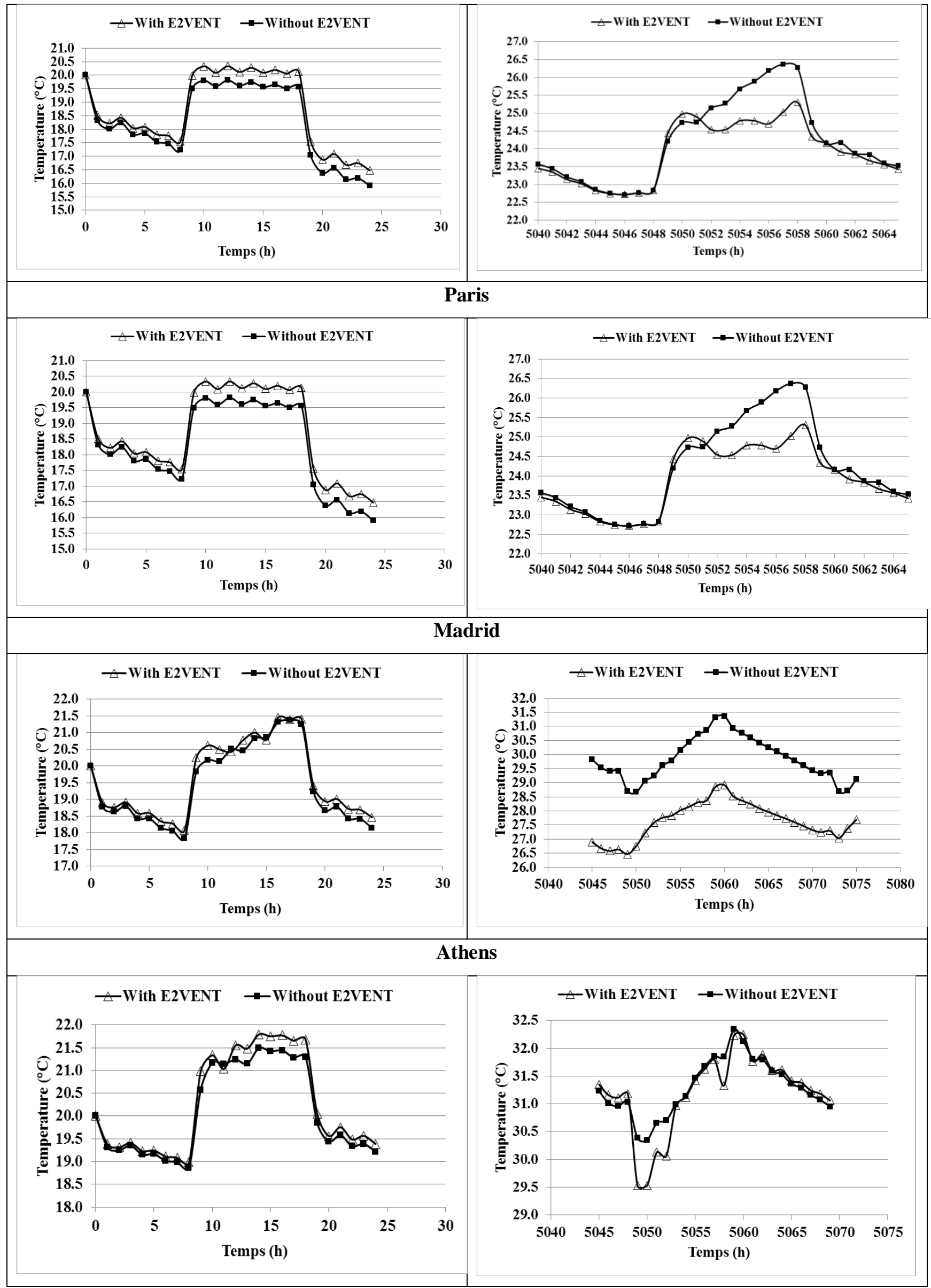


Table 5: Temperature for different climates

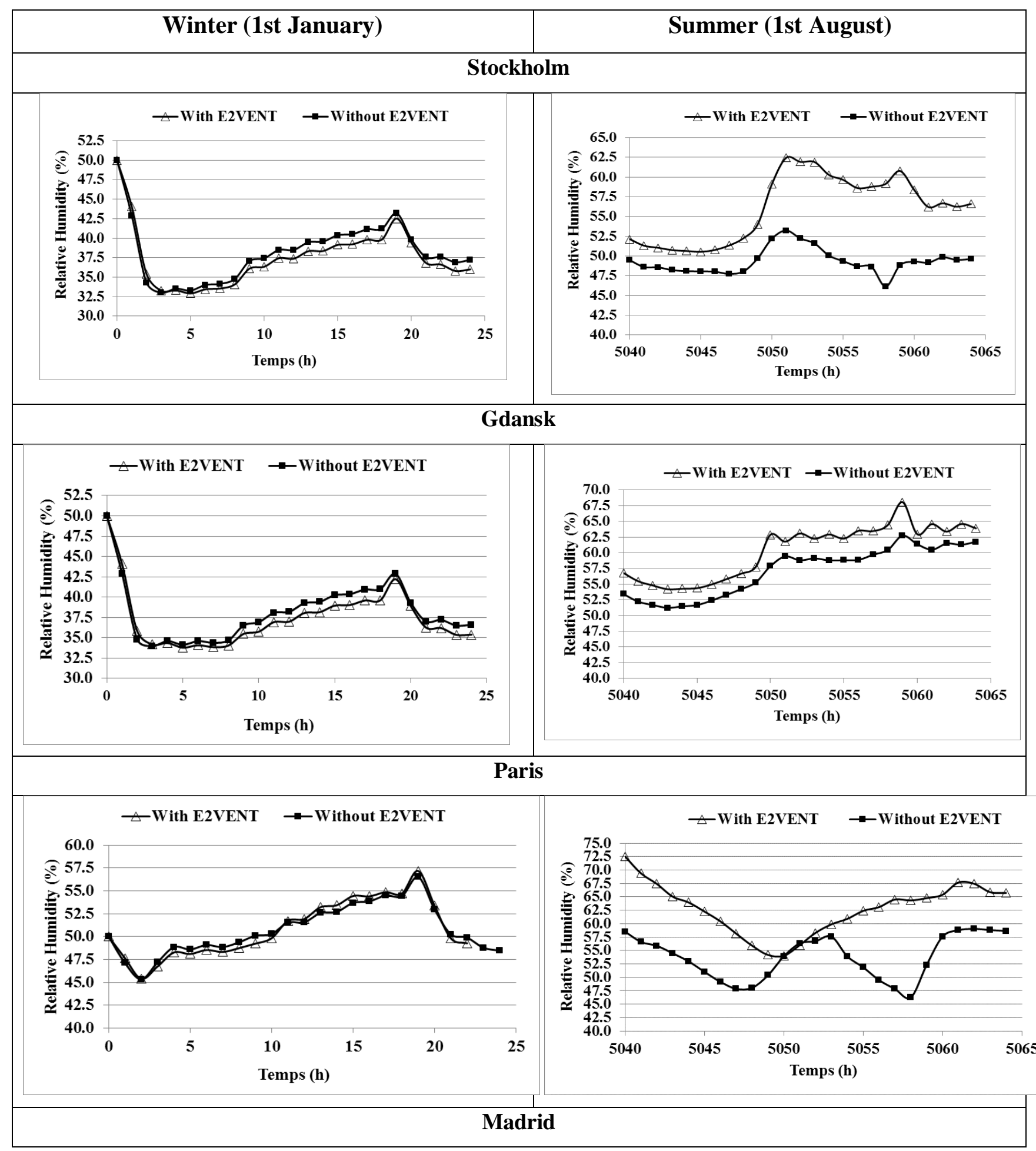



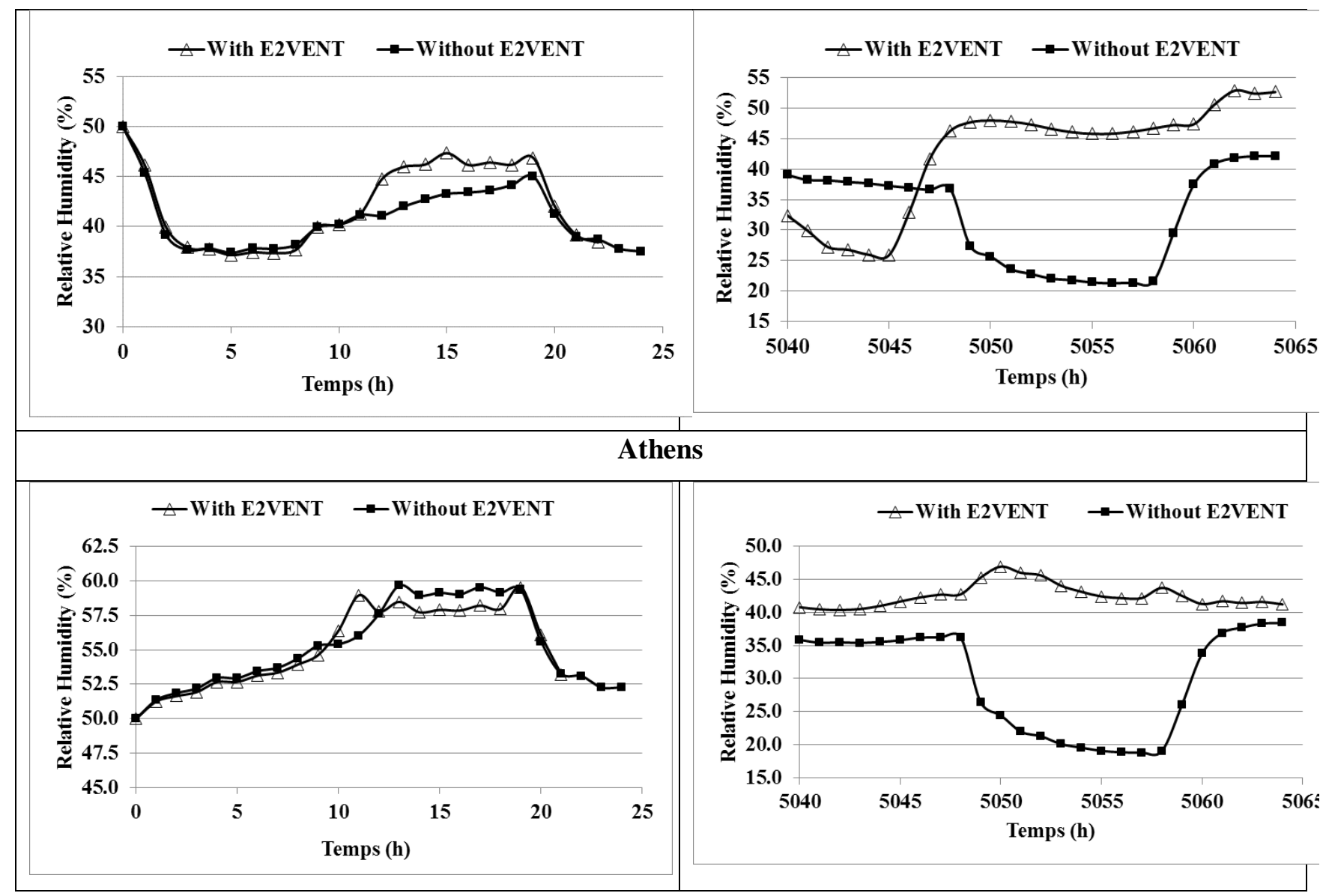

Table 6: Relative humidity levels for different climates

In order to assess the impact of the climatic condition on the thermal comfort level over the winter duration, the number of hours during which the indoor air temperature is below $20{ }^{\circ} \mathrm{C}$ (lower limit set-point) and $21{ }^{\circ} \mathrm{C}$ (set-point) were estimated. During summer, the numbers of hours in which the indoor air temperature is above $26^{\circ} \mathrm{C}$ (set-point temperature), $27^{\circ} \mathrm{C}$ (upper limit set-point) and $29^{\circ} \mathrm{C}$ are also counted. Fig. 14 presents the number of hours that the indoor temperatures is less than $20{ }^{\circ} \mathrm{C}$ and $21{ }^{\circ} \mathrm{C}$ with and without the E2VENT system and the reduction of discomfort between the reference case without E2VENT and the building with E2VENT system for different climates. Fig. 15 shows that the E2VENT system can significantly reduce the number of discomfort hours compared to the reference case without E2VENT system. This reduction is related to the climatic conditions, and decreases with the reduced winter severity of the climate. The reduction of discomfort varies from $23 \%$ (for Athens) to $4.7 \%$ (for Stockholm) for Tin $>20^{\circ} \mathrm{C}$ and from $6 \%$ (for Athens) to $2 \%$ (for Stockholm) for Tin $>21^{\circ} \mathrm{C}$. 

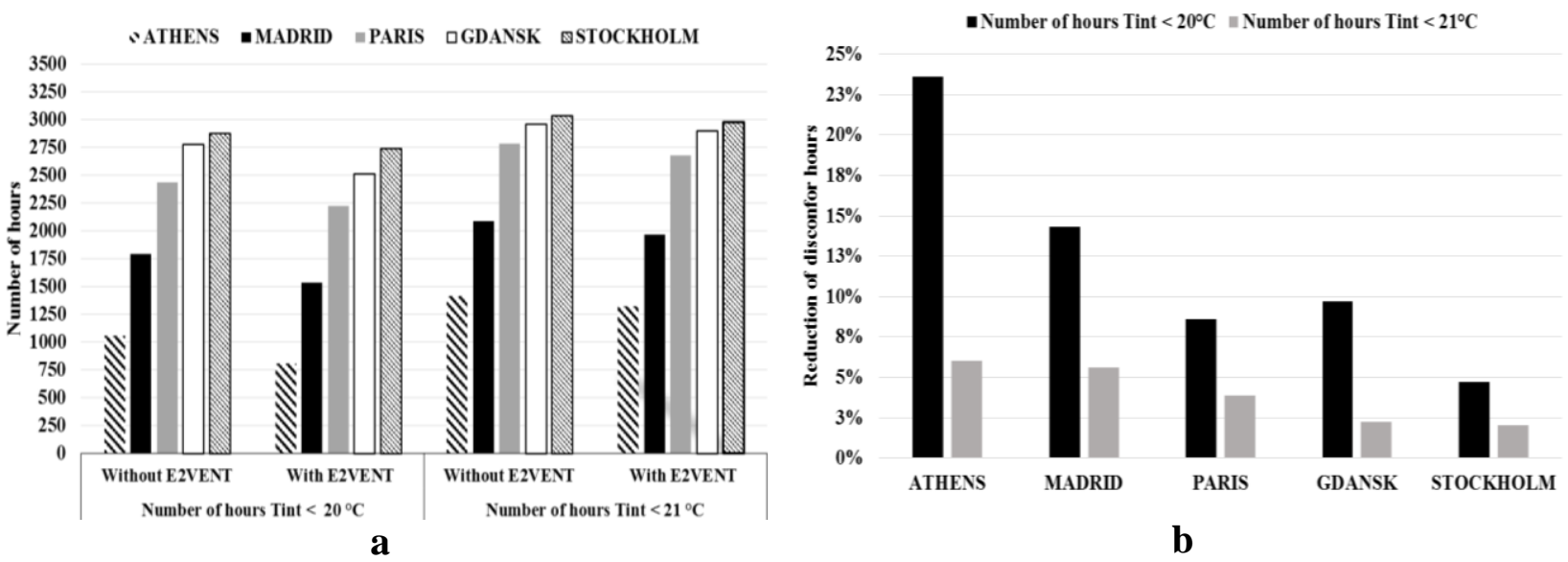

Fig. 14: a) Number of hours Tint $<20^{\circ} \mathrm{C}$ and Tint $<21{ }^{\circ} \mathrm{C}$ with and without E2VENT system for different climates b) Reduction of discomfort hours by the E2VENT system for different climates.

Fig. 15 presents the numbers of hours for indoor temperatures exceeding $26^{\circ} \mathrm{C}$ (set-point temperature), $27^{\circ} \mathrm{C}$ (upper limit set-point) and $29{ }^{\circ} \mathrm{C}$ and reduction in summer discomfort hours between the reference case without E2VENT and the building with E2VENT system. Fig.16a shows that the E2VENT system can significantly reduce the number of discomfort hours compared to the reference case without the system. This summer discomfort reduction is also the function of climate conditions, and decrease with the reduced summer severity of the climate. The reduction of discomfort varies from $44 \%$ (Gdansk) to $8 \%$ (Athens) for Tin > $26{ }^{\circ} \mathrm{C}$, from $100 \%$ (Gdansk) to $8.9 \%$ (Athens) for Tin $>27{ }^{\circ} \mathrm{C}$, and from $14.7 \%$ (Madrid) to $10.9 \%$ (Stockholm) for Tin $>29^{\circ} \mathrm{C}$. For the indoor temperature exceeding $29^{\circ} \mathrm{C}$, the number of hours discomfort is zero for lower winter severity climates, e.g., Stockholm, Gdansk and Paris.

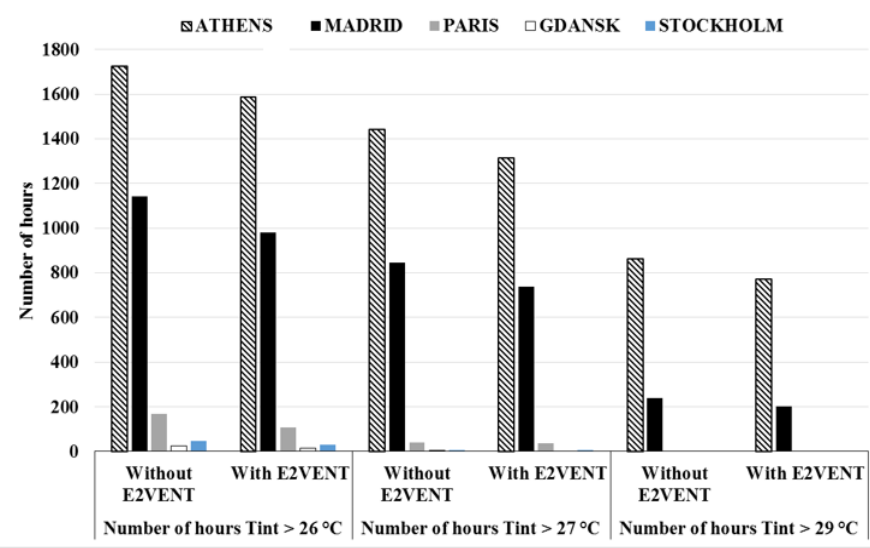




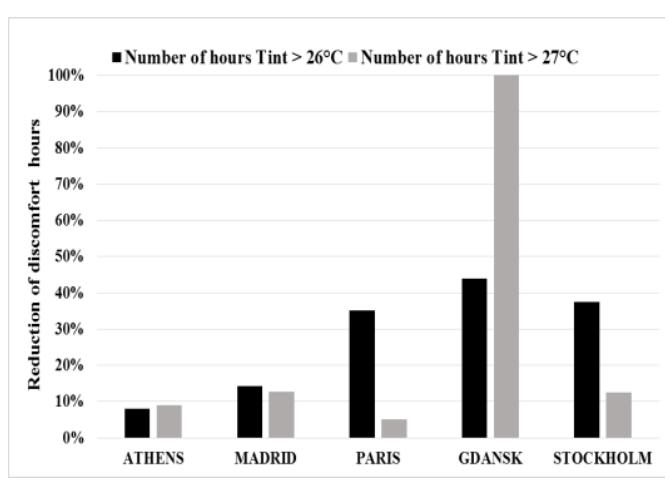

b

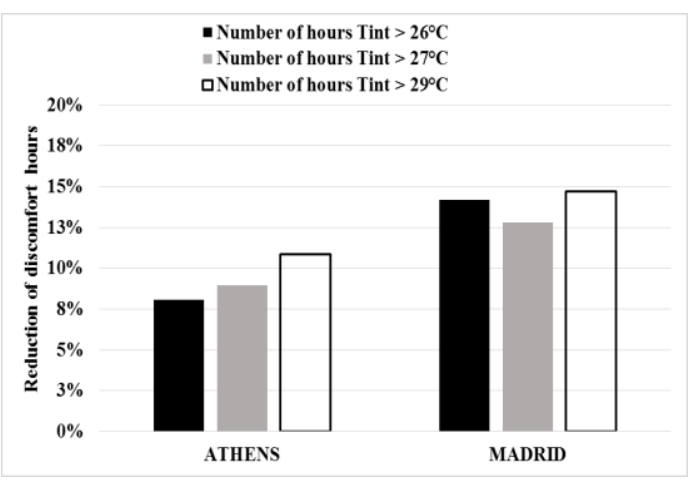

C

Fig. 15: a) Number of hours Tint $>26{ }^{\circ} \mathrm{C}$, Tint $>27{ }^{\circ} \mathrm{C}$ and Tint $>28{ }^{\circ} \mathrm{C}{ }^{\circ} \mathrm{C}$ with and without E2VENT system for different climates b) Reduction of discomfort hours by the E2VENT system for Tint $>26^{\circ} \mathrm{C}$, Tint $>27^{\circ} \mathrm{C}$ c) Reduction of discomfort hours by the E2VENT system for Tint $>26^{\circ} \mathrm{C}$, Tint $>27^{\circ} \mathrm{C}$ Tint $>29^{\circ} \mathrm{C}$.

\subsection{Energy Efficiency of the E2VENT system for different climates}

Heating and cooling loads: Table 7 shows the annual final energy demands for heating and cooling for the examined representative climatic zones. Apart from the demand, Table 7 also shows the percentage of energy saving relative to heating, cooling and total loads.

\begin{tabular}{|l|c|c|c|c|c|c|c|c|c|}
\hline & \multicolumn{2}{|c|}{ Reference Building } & \multicolumn{2}{c|}{ Building with E2VENT } & \multicolumn{2}{c|}{ Total loads } & \multicolumn{2}{c|}{ Energy load Saving } \\
\cline { 2 - 11 } \multicolumn{1}{c|}{ Location } & $\begin{array}{c}\text { Heating } \\
{[\mathrm{kWh}]}\end{array}$ & $\begin{array}{c}\text { Cooling } \\
{[\mathrm{kWh}]}\end{array}$ & $\begin{array}{c}\text { Heating } \\
{[\mathrm{kWh}]}\end{array}$ & $\begin{array}{c}\text { Cooling } \\
{[\mathrm{kWh}]}\end{array}$ & $\begin{array}{c}\text { Reference } \\
\text { Building } \\
{[\mathrm{kWh}]}\end{array}$ & $\begin{array}{c}\text { Building with } \\
\text { E2VENT } \\
{[\mathrm{kWh}]}\end{array}$ & Heating & Cooling & $\begin{array}{c}\text { Total load } \\
\text { Saving }\end{array}$ \\
\hline ATHENS & $\mathbf{3 7 2 . 0}$ & $\mathbf{1 0 6 0 . 0}$ & $\mathbf{2 1 1 . 3}$ & $\mathbf{9 2 3 . 0}$ & $\mathbf{1 4 3 2 . 0}$ & $\mathbf{1 1 3 4 . 3}$ & $\mathbf{4 3 . 2 \%}$ & $\mathbf{1 2 . 9 \%}$ & $\mathbf{2 0 . 8 \%}$ \\
\hline MADRID & $\mathbf{1 0 1 8 . 4}$ & $\mathbf{5 9 3 . 0}$ & $\mathbf{7 0 1 . 3}$ & $\mathbf{4 8 4 . 0}$ & $\mathbf{1 6 1 1 . 4}$ & $\mathbf{1 1 8 5 . 3}$ & $\mathbf{3 1 . 1 \%}$ & $\mathbf{1 8 . 4 \%}$ & $\mathbf{2 6 . 4 \%}$ \\
\hline PARIS & $\mathbf{1 8 6 7 . 0}$ & $\mathbf{3 3 . 9}$ & $\mathbf{1 4 1 7 . 0}$ & $\mathbf{1 7 . 5}$ & $\mathbf{1 9 0 0 . 9}$ & $\mathbf{1 4 3 4 . 5}$ & $\mathbf{2 4 . 1 \%}$ & $\mathbf{4 8 . 3 \%}$ & $\mathbf{2 4 . 5 \%}$ \\
\hline GDANSK & $\mathbf{2 7 4 7 . 0}$ & 1.3 & $\mathbf{2 1 7 3 . 0}$ & $\mathbf{0 . 0}$ & $\mathbf{2 7 4 8 . 3}$ & $\mathbf{2 1 7 3 . 0}$ & $\mathbf{2 0 . 9 \%}$ & $\mathbf{1 0 0 . 0 \%}$ & $\mathbf{2 0 . 9 \%}$ \\
\hline STOCKHOLM & $\mathbf{3 2 4 9 . 0}$ & $\mathbf{3 . 2}$ & $\mathbf{2 6 5 4 . 0}$ & $\mathbf{0 . 9}$ & $\mathbf{3 2 5 2 . 2}$ & $\mathbf{2 6 5 4 . 9}$ & $\mathbf{1 8 . 3 \%}$ & $\mathbf{7 2 . 0 \%}$ & $\mathbf{1 8 . 4 \%}$ \\
\hline & & & & & & Average & $\mathbf{2 7 . 5 \%}$ & $\mathbf{5 0 . 3 \%}$ & $\mathbf{2 2 . 2 \%}$ \\
\hline
\end{tabular}

Table 7: Energy consumption of the building for different climates

Heating: Table 7 indicates that the energy demand saving by the E2VENT system is highly dependent upon the weather conditions (e.g., Athens, Madrid). The heat energy saving increases with the increased winter severity. In the climates with lower winter severely (e.g. Stockholm, Gdansk), the heat energy savings are greater than those of the climate with greater winter severity level. For example, the heat energy saving is smaller in Stockholm where the climate is severe and higher in Athens where the climate is warmer. The heat energy saving of $18 \%$ in Stockholm is mainly due to the heat recovery with a thermal efficiency $>89 \%$ (for all climates) and the ventilated air cavity. For this climate, the LHTES 
is not in operation during the winter period. As shown in Table 8, the operation of the LHTES increases with the increased winter severity. The greater heat energy saving in Athens is owing to the lower winter severity and longer operating period of the LHTES, which will benefit to the efficiency enhancement of the whole E2VENT system. For our case, the average heat energy saving is around $28 \%$.

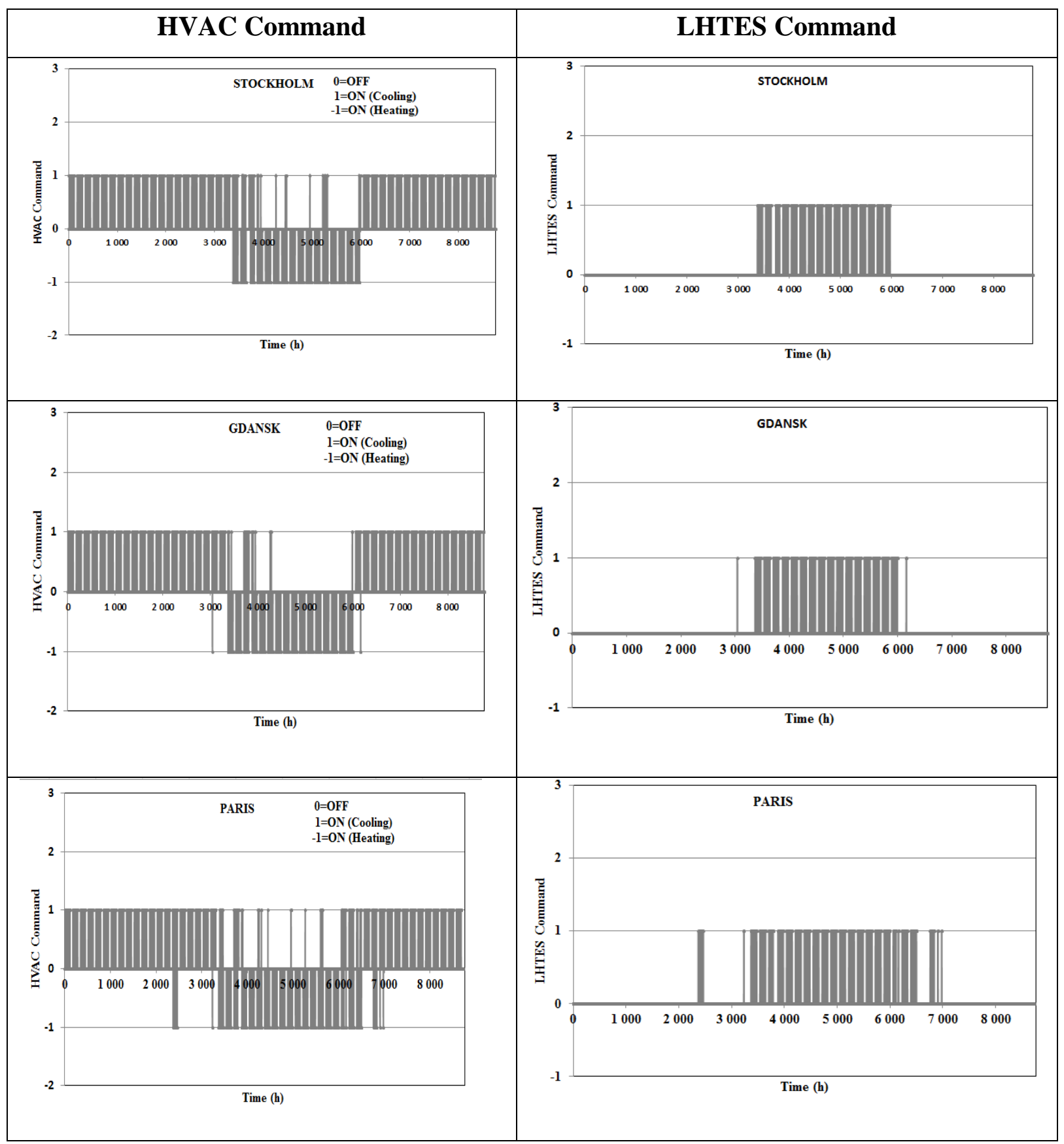




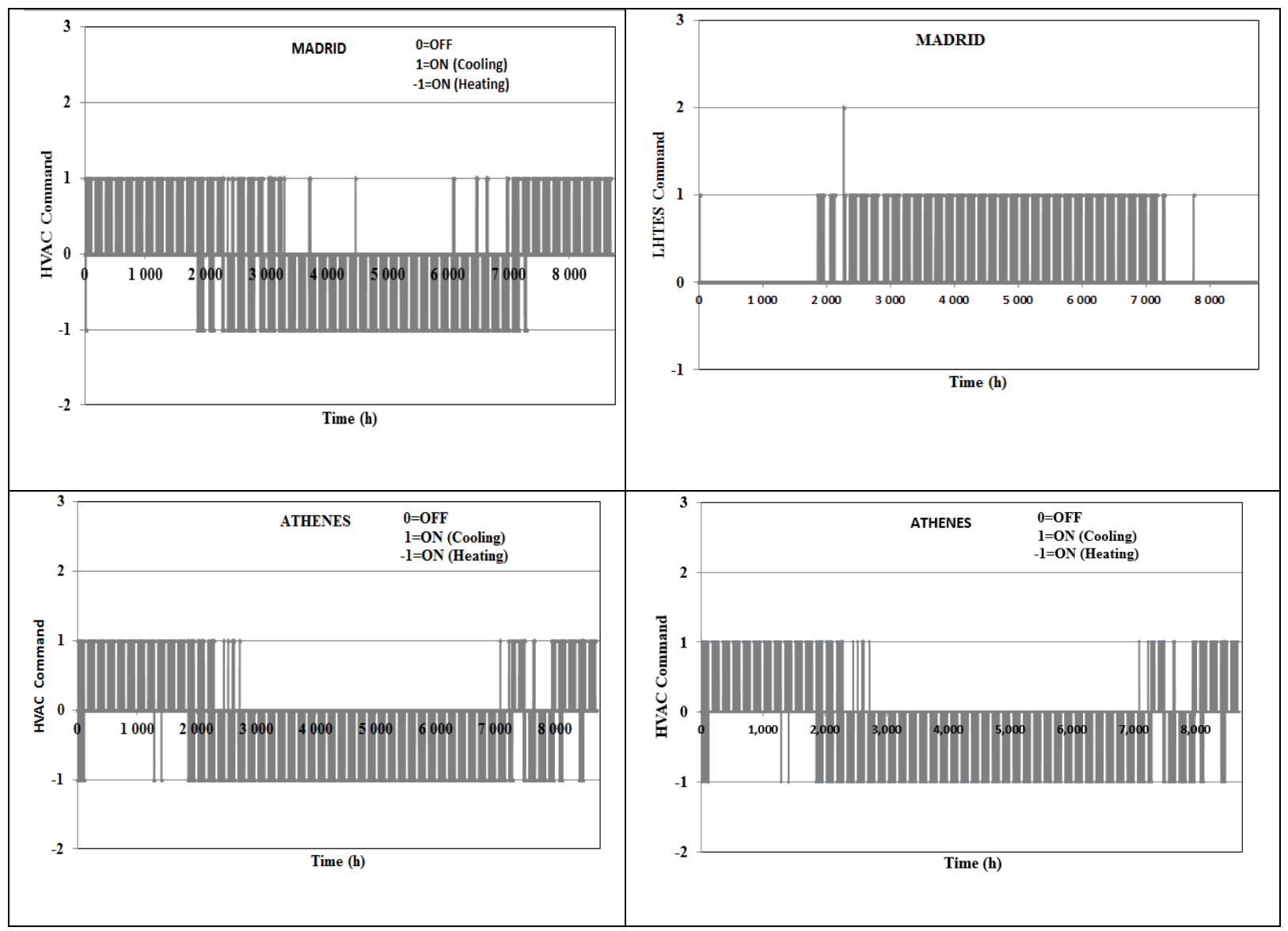

Table 8: HVAC and LHTES operation

Fig.16 shows the variation of the PCM temperature during a single year operation. The variation is largely dependent upon the climatic condition and is usually higher during the heating period when the temperature is less than $21^{\circ} \mathrm{C}$ that can prevent increase in the heating load. During the cooling period, however, the PCM temperature is lower than the cooling set point of $26^{\circ} \mathrm{C}$ that allows the cooling load to be reduced.
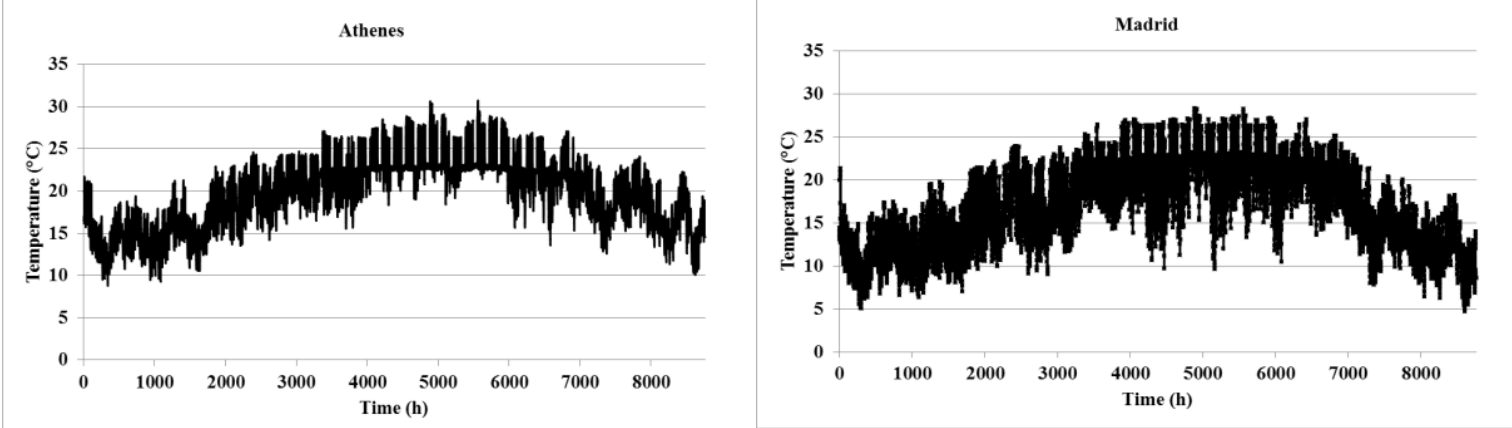

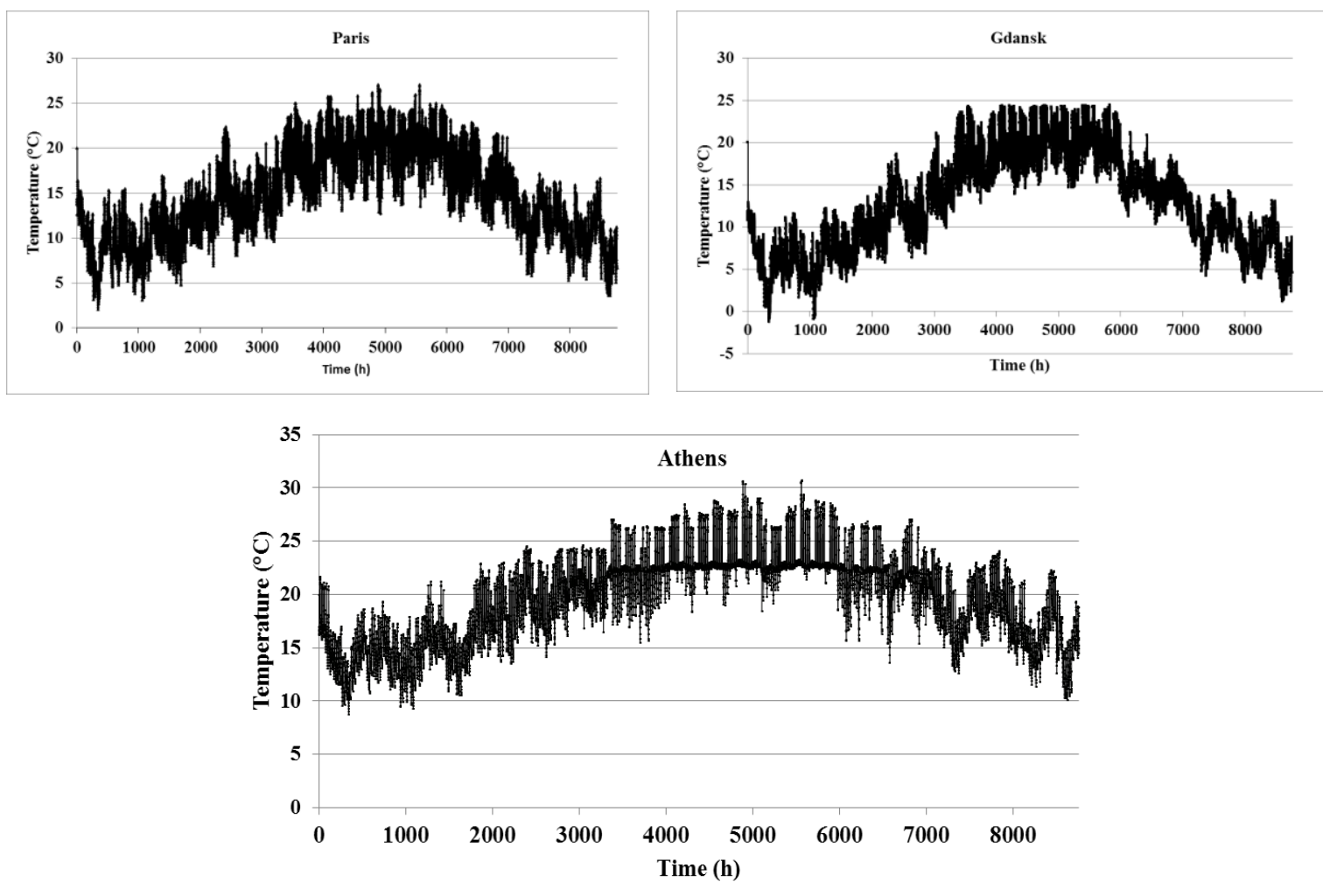

Fig. 16: Temperatures of the PCM for different locations.

Figure 17 presents the COP of the SMHRU that is defined as the ratio of recovered heat energy and electricity power use (Equation 8). Figure 20 shows that the SMHRU can achieve an efficient operation throughout the year, particularly during the winter period. A COP of less than 2.5 indicates that the heat recovery is less efficient than the boiler-based air heating system with thermal efficiency of $75 \%$ [36]. The percentage of the operational time for COP $<2.5$ is largely dependent upon the climatic condition and decreases proportionally with the summer severity, varying from $61.2 \%$ (Athens) to $23.3 \%$ (Gdansk). This indicates that for Athens and Gdansk, the heat recovery operating time is $61.3 \%$ and $23.3 \%$ of the total operational time in order to reduce the energy consumption of the HVAC systems.

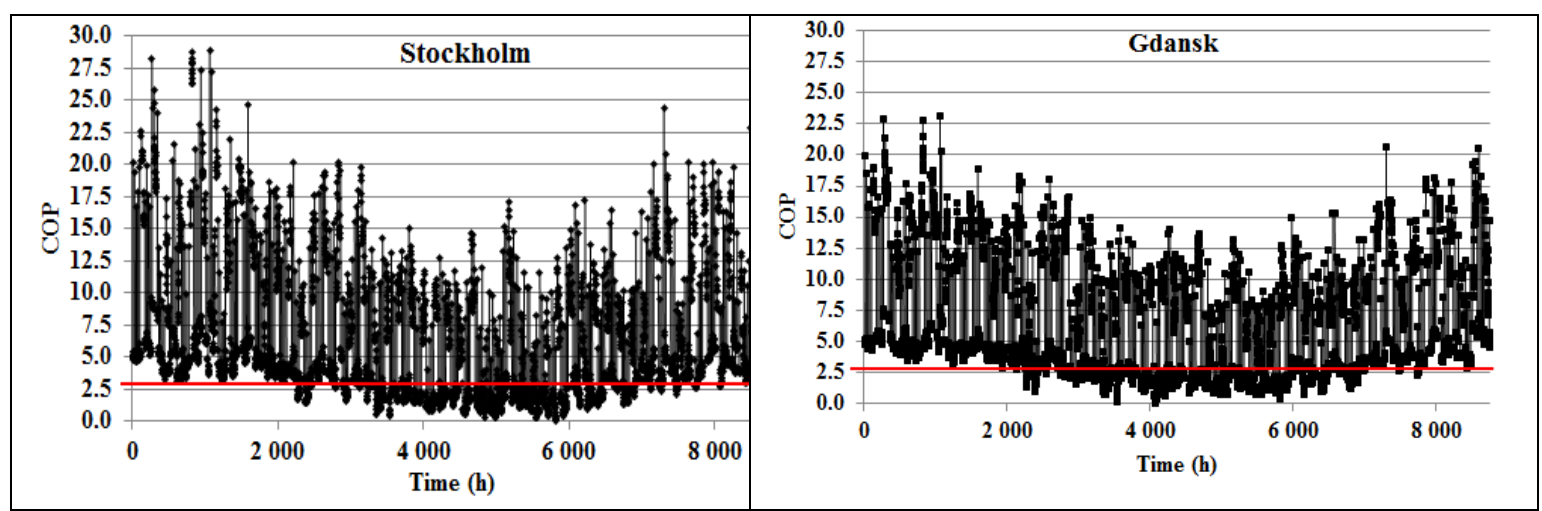




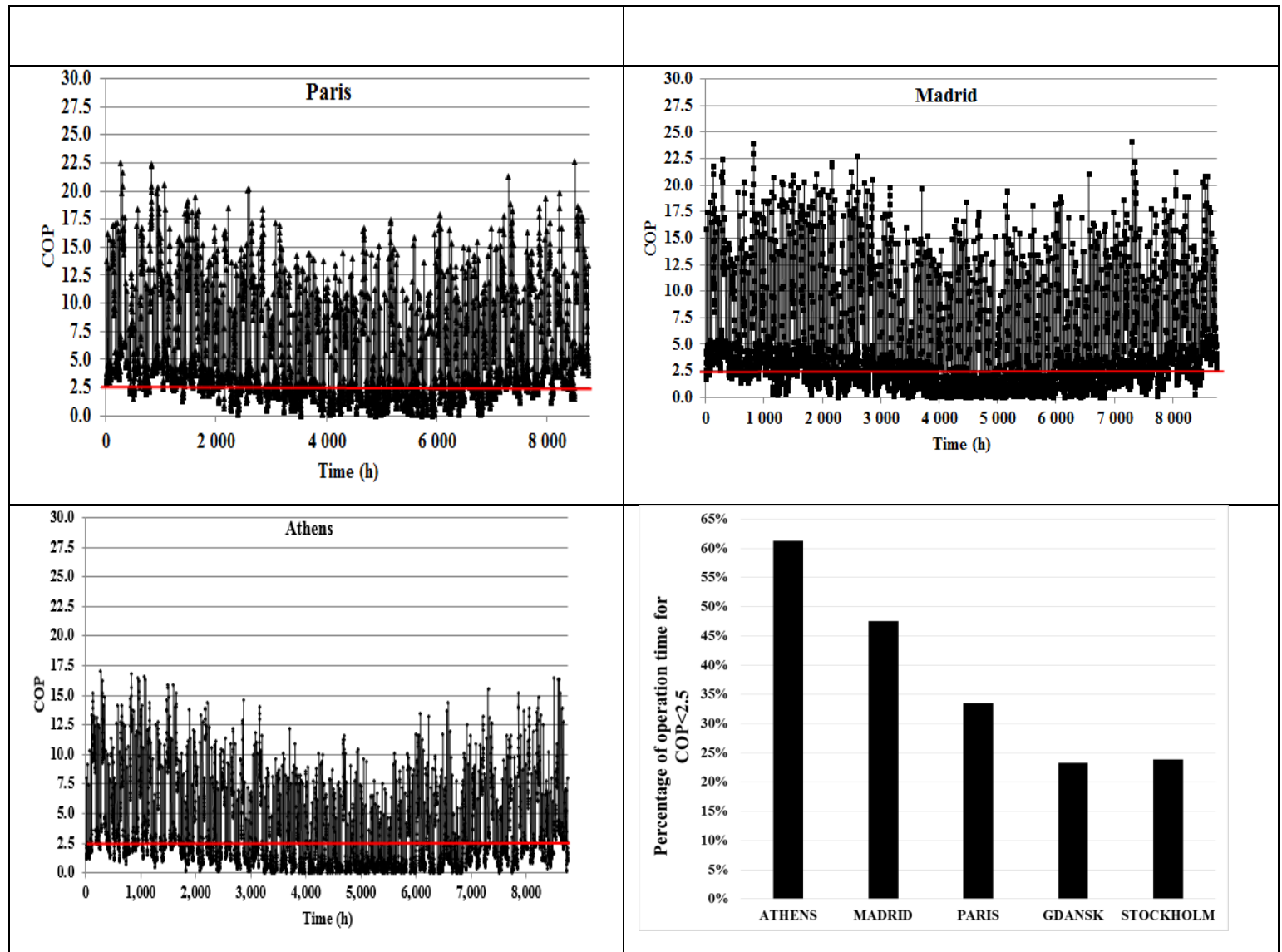

Fig. 17: COP of the SMHRU for different climates and the percentage of operation time for COP $<2.5$

Cooling: Table 8 shows that the energy demand for cooling is largely dependent upon the weather condition (e.g. Athens, Madrid). The cooling loads saving decreases with the reduced summer severity. In the climates with lower summer severity (Stockholm, Gdansk, Paris), the cooling energy savings are greater than those with greater summer severity. The cooling loads saving is smaller in Athens where the summer climate is significantly severe and larger in the cold climate when the severity is lower. The heat energy saving of $100 \%$ is achieved in Gdansk, owing to the lower summer severity and the higher efficiency of E2VENT system (LHTES and SMHRU).

Total energy demand for cooling and heating: The total energy saving is greater in the medium climates with no severe winter condition and no severe summer condition (e.g. Paris, Madrid). In these climates the building would benefit significantly from the increased efficiency of the whole E2VENT system. 
Electricity consumption of the HVAC system: As presented in 2.3.3, the energy efficiency of the E2VENT system $\eta_{E 2 V E N T}$ will be quantified by its ability to decrease the primary energy used for cooling and heating. Figure 18 presents the HVAC electricity saving achieved by the E2VENT system, which is largely dependent upon the climate condition. The electrical energy saving increases with the decrease of the winter severity. The saving is smaller in severe winter condition where the HVAC fan operates during the majority time of the season.
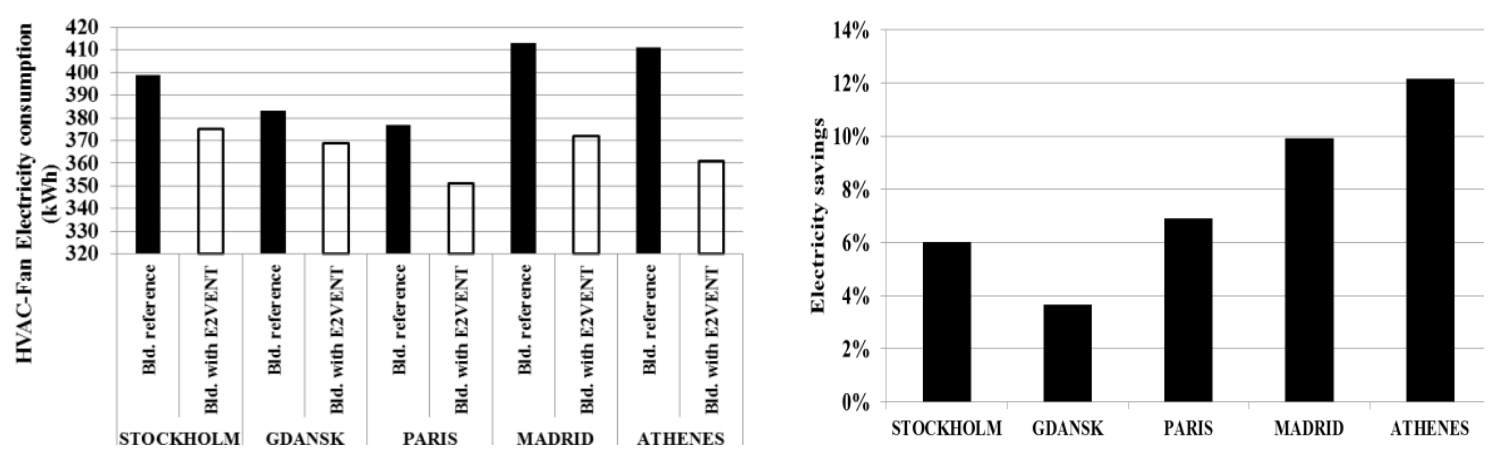

Fig. 18: HVAC Fan Electricity consumption

SMHRU and LHTES electricity consumption: The electricity consumption of the SMHRU for all climates is the same because it is based on the occupancy schedule that is the same for all climates. The electricity consumption of the SMHRU is 6 to 10 times higher than the LHTES because of the lower operational timing of the LHTES.
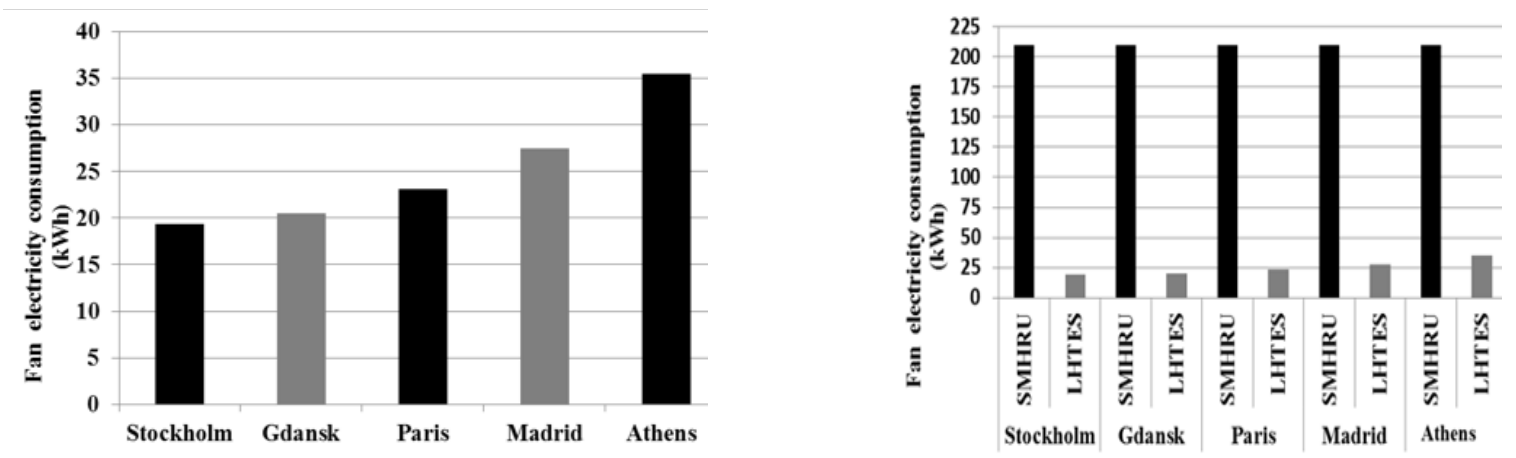

Fig. 19: SMHRU and LHTES Fan Electricity consumption

Total Electricity consumption: Compared to the reference case, the building with the E2VENT system consumes a slightly higher amount of electricity because of the energy consumption of SMHRU Fans (Fig. 20). For the reference case, a single supply fan based ventilation system is considered. 


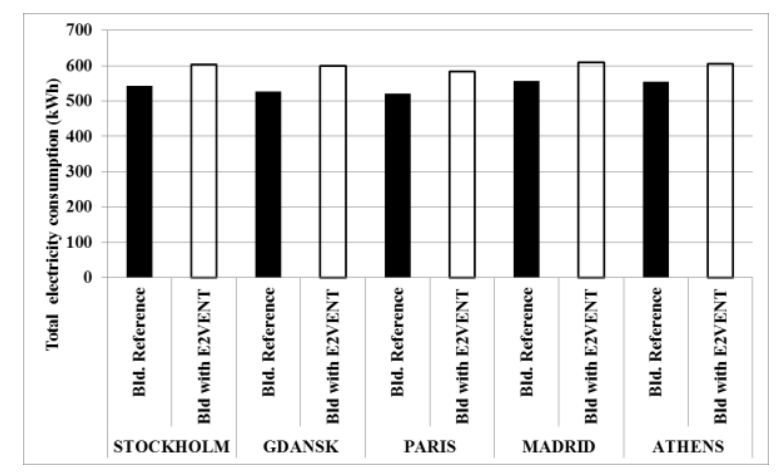

Fig. 20: SMHRU and LHTES Fan Electricity consumption

Total Primary Energy consumption: To estimate the primary energy consumption, we supposed that, the heating is provided by gas (conversion coefficient=1), and the cooling is provided by an air heat pump with $\mathrm{COP}=3$. Table 10 presents the primary energy saving.

\begin{tabular}{|l|c|c|c|c|c|c|c|c|}
\hline \multirow{2}{*}{ Location } & \multicolumn{2}{|c|}{ Reference Building } & \multicolumn{2}{c|}{ Building with E2VENT } & \multicolumn{2}{c|}{ Total loads } & \multicolumn{2}{c|}{ Energy load Saving } \\
\cline { 2 - 9 } & $\begin{array}{c}\text { Heating } \\
{[\mathrm{kWh}]}\end{array}$ & $\begin{array}{c}\text { Cooling } \\
{[\mathrm{kWh}]}\end{array}$ & $\begin{array}{c}\text { Heating } \\
{[\mathrm{kWh}]}\end{array}$ & $\begin{array}{c}\text { Cooling } \\
{[\mathrm{kWh}]}\end{array}$ & $\begin{array}{c}\text { Reference } \\
\text { Building } \\
{[\mathrm{kWh}]}\end{array}$ & $\begin{array}{c}\text { Building with } \\
\text { E2VENT } \\
{[\mathrm{kWh}]}\end{array}$ & $\begin{array}{c} \\
\text { Heating }\end{array}$ & Cooling \\
\hline ATHENS & $\mathbf{3 7 2 . 0}$ & $\mathbf{8 8 3 . 3}$ & $\mathbf{2 1 1 . 3}$ & $\mathbf{7 6 9 . 2}$ & $\mathbf{1 2 5 5 . 3}$ & $\mathbf{1 0 3 1 . 5}$ & $\mathbf{4 3 . 2 \%}$ & $\mathbf{1 2 . 9 \%}$ \\
\hline MADRID & $\mathbf{1 0 1 8 . 4}$ & $\mathbf{4 9 4 . 2}$ & $\mathbf{7 0 1 . 3}$ & $\mathbf{4 0 3 . 3}$ & $\mathbf{1 5 1 2 . 6}$ & $\mathbf{1 1 5 6 . 6}$ & $\mathbf{3 1 . 1 \%}$ & $\mathbf{1 8 . 4 \%}$ \\
\hline PARIS & $\mathbf{1 8 6 7 . 0}$ & $\mathbf{2 8 . 2}$ & $\mathbf{1 4 1 7 . 0}$ & $\mathbf{1 4 . 6}$ & $\mathbf{1 8 9 5 . 2}$ & $\mathbf{1 4 9 3 . 6}$ & $\mathbf{2 4 . 1 \%}$ & $\mathbf{4 8 . 3 \%}$ \\
\hline GDANSK & $\mathbf{2 7 4 7 . 0}$ & $\mathbf{1 . 1}$ & $\mathbf{2 1 7 3 . 0}$ & $\mathbf{0 . 0}$ & $\mathbf{2 7 4 8 . 1}$ & $\mathbf{2 2 4 5 . 0}$ & $\mathbf{2 0 . 9 \%}$ & $\mathbf{1 0 0 . 0 \%}$ \\
\hline STOCKHOLM & $\mathbf{3 2 4 9 . 0}$ & $\mathbf{2 . 7}$ & $\mathbf{2 6 5 4 . 0}$ & $\mathbf{0 . 8}$ & $\mathbf{3 2 5 1 . 7}$ & $\mathbf{2 7 1 5 . 8}$ & $\mathbf{1 8 . 3 \%}$ & $\mathbf{7 2 . 0 \%}$ \\
\hline & & & & & & Average & $\mathbf{2 7 . 5 \%}$ & $\mathbf{5 0 . 3 \%}$ \\
\hline
\end{tabular}

Table 9: Primary energy consumption

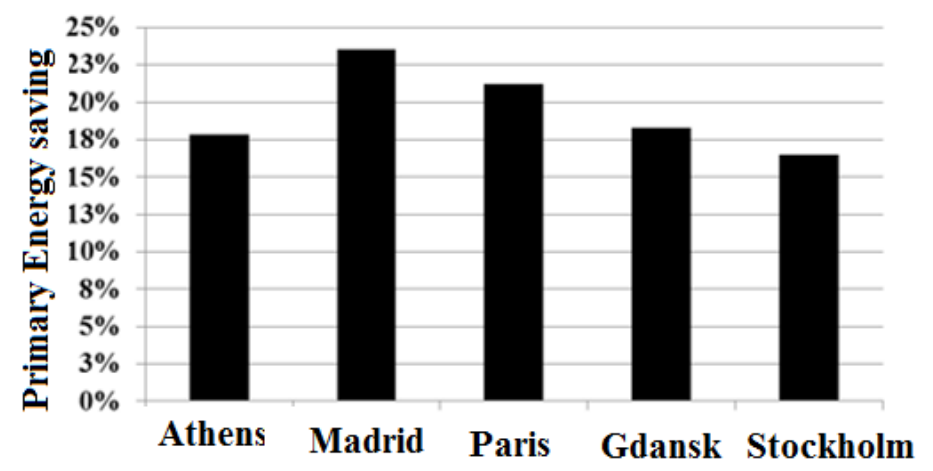

Fig. 21: Primary electricity saving

This energy consumption analysis shows that the E2VENT system can be efficient for different climates. By this way, it extends the operation of OVFs for different climates and seasons. For any given climate, the E2VENT model developed can be used by the building designers in order to assess and optimize the performance of the system when being integrated in the building.

Comparison of Energy loads of SMHRU+LHTES and SMHRU Only: Table 10 presents the energy loads of the building with E2VENT system and with SMHRU Only. During heating period, 
the impact of the LHTES on heating is very light, representing only $0.5-1.3 \%$ of the total load at the warmer climates (e.g. Paris, Madrid, Athens) and $0 \%$ of the total load at the cold climates. This is owing to the fact that the PCM temperature (Fig. 16) is lower than the heating set-point at the majority time of the heating season. The percentage falls slightly during the mid-season owing to the increased room temperature. During this period, the efficiency of the system is almost same as that of the SMHRU and the cavity. However, during the cooling season, the impact of the LHTES on the energy load becomes significant, particularly at the cold climates where the cooling needs are slightly lower.

\begin{tabular}{|l|c|c|c|c|c|c|}
\hline \multirow{2}{*}{ LOCATION } & \multicolumn{2}{|c|}{$\begin{array}{c}\text { BUILDING } \\
\text { WITH SMHRU }\end{array}$} & \multicolumn{2}{c|}{$\begin{array}{c}\text { BUILDING WITH } \\
\text { (LHTES+SMHRU) }\end{array}$} & \multicolumn{2}{c|}{ Energy Load Saving } \\
\cline { 2 - 7 } & $\begin{array}{c}\text { Heating } \\
{[\mathbf{k W h}]}\end{array}$ & $\begin{array}{c}\text { Cooling } \\
{[\mathbf{k W h}]}\end{array}$ & $\begin{array}{c}\text { Heating } \\
{[\mathbf{k W h}]}\end{array}$ & $\begin{array}{c}\text { Cooling } \\
{[\mathbf{l k W h}]}\end{array}$ & Heating & Cooling \\
\hline ATHENS & 214.0 & 1061.8 & 211.3 & 923.0 & $1.3 \%$ & $13.1 \%$ \\
\hline MADRID & 708.0 & 601.7 & 701.3 & 484.0 & $0.9 \%$ & $19.6 \%$ \\
\hline PARIS & 1424.0 & 33.4 & 1417.0 & 17.5 & $0.5 \%$ & $47.6 \%$ \\
\hline GDANSK & 2173.0 & 1.4 & 2173.0 & 0.0 & $0.0 \%$ & $100.0 \%$ \\
\hline STOCKHOLM & 2654.0 & 3.4 & 2654.0 & 0.9 & $0.0 \%$ & $73.5 \%$ \\
\hline & & & & Average & $\mathbf{0 . 5 \%}$ & $\mathbf{5 0 . 7 \%}$ \\
\hline
\end{tabular}

Table 10: Energy loads comparison: SMHRU Only vs. SMHRU+LHTES

Impact of the infiltration rate: As the E2VENT system is an "air-only" system, the air tightness of the building could have a significant impact on the efficiency of the E2VENT system. In this study, the impact of the infiltration rate to the E2VENT efficiency is investigated by considering $50 \%$ of the infiltration rate as to the previous case, thus giving the $\mathrm{ACH}$ value of 0.5 . Figure 23 presents the impact of infiltration on energy loads. In this case, the energy load saving is increased from 22 to $32 \%$. This indicates that by improving the infiltration of the building the efficiency of E2VENT system can be significantly increased. This fact that the E2VENT system is most efficient for airtight buildings is interesting because in all European countries national regulations require a steady reduction in thermal transmittance values, which involves the increase of the building air tightness [37].
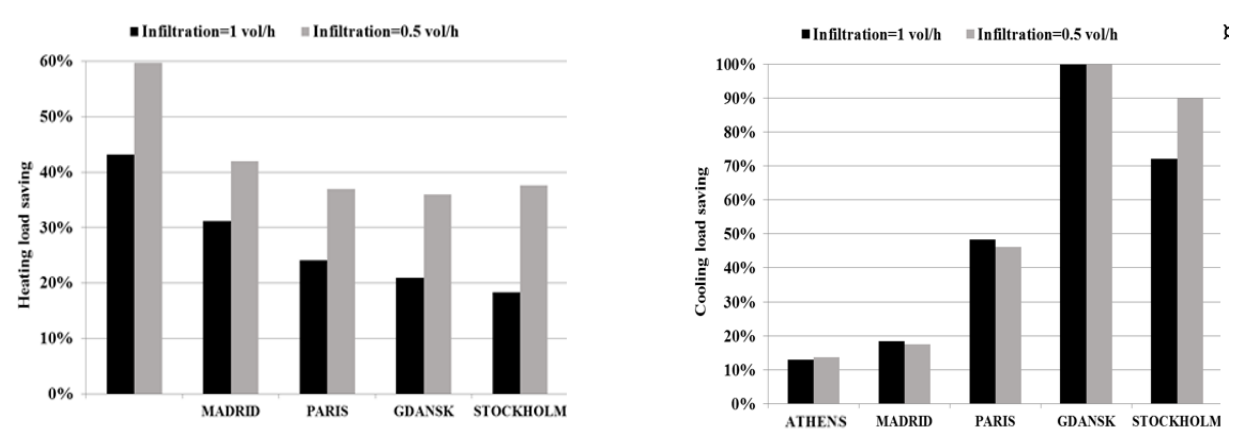


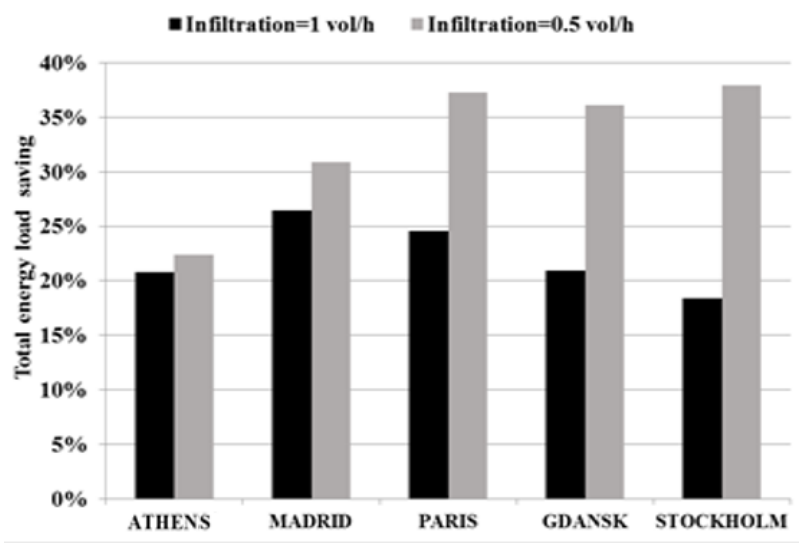

Fig. 22: Impact of infiltration on heating, cooling and total energy load savings

\section{b. Comparison between the E2VENT retrofitting and the traditional retrofitting solutions}

Based on the building shown in Fig. 14, comparison between the two types of retrofitting methods is carried out. During this process, three cases are investigated:

- Case 1: The building itself without any retrofitting (no insulation $U_{\text {wall }}=0,5$ $\mathrm{W} / \mathrm{m}^{2} / \mathrm{K}$, windows with $\left.\mathrm{U}_{\mathrm{w}}=2,5 \mathrm{~W} / \mathrm{m}^{2} / \mathrm{K}\right)+$ supply mechanical ventilation.

- Case 2: Traditional retrofitting solution: Renovated with a business as usual solution. Insulation + ventilated cladding on the whole exterior façade + supply mechanical ventilation.

- Case 3: E2VENT retrofitting solution: Renovated with E2VENT solution: insulation + cladding on the whole façade + SMHRU and LHTES.

Table 11 summarized all input parameters of the different systems.

\begin{tabular}{|c|c|c|c|}
\hline Parameters & $\begin{array}{l}\text { The building } \\
\text { itself without } \\
\text { any } \\
\text { retrofitting }\end{array}$ & $\begin{array}{l}\text { Traditional } \\
\text { retrofitting } \\
\text { solution }\end{array}$ & $\begin{array}{c}\text { E2VENT retrofitting } \\
\text { solution }\end{array}$ \\
\hline $\begin{array}{l}\text { Wall, roof, and floor } \\
\text { characteristics }\end{array}$ & \multicolumn{3}{|c|}{$\begin{array}{c}\text { Uvalue outside wall }=0.5 \mathrm{~W} / \mathrm{m}^{2} / \mathrm{K} \\
\text { Uvalue Roof }=0.5 \mathrm{~W} / \mathrm{m}^{2} / \mathrm{K} \\
\text { Uvalue Ground }=0.3 \mathrm{~W} / \mathrm{m}^{2} / \mathrm{K}\end{array}$} \\
\hline Infiltration rate & \multicolumn{3}{|c|}{$1 \mathrm{~h}^{-1}$ (Value Convenient with EN 13779 [35] ) } \\
\hline Insulation level & No Insulation & $\begin{array}{l}\text { Insulation of the } \\
\text { ventilated façade }\end{array}$ & $\begin{array}{l}\text { Insulation of the } \\
\text { ventilated façade }\end{array}$ \\
\hline $\begin{array}{lll}\text { Glass and } & \text { door } \\
\text { properties } & & \end{array}$ & \multicolumn{3}{|c|}{ Window U_value $=2.5 \mathrm{~W} / \mathrm{m}^{2} / \mathrm{K} ;$ Door U_value $=0.5 \mathrm{~W} / \mathrm{m}^{2} / \mathrm{K}$} \\
\hline Infiltration rate & \multicolumn{3}{|c|}{$1 \mathrm{~h}^{-1}$} \\
\hline Type of HVAC systems & cooler & -Air cooler (121 b) & -SMHRU \\
\hline
\end{tabular}




\begin{tabular}{|c|c|c|c|}
\hline & $\begin{array}{l}(121 \text { b) } \\
\text {-Air heater }(92 \\
\text { b) } \\
\text {-Supply } \\
\text { ventilation } \\
\text { (Occupied: } 0.7 \\
\text { Vol/h, } \\
\text { Unoccupied: } \\
0.2) \text {. }\end{array}$ & $\begin{array}{l}\text {-Air heater }(92 \mathrm{~b}) \\
\text {-Supply ventilation } \\
\text { (Occupied: } 0.7 \\
\text { Vol/h, } \\
\text { Unoccupied: } 0.2) .\end{array}$ & $\begin{array}{l}\text { recovery ventilation } \\
\text { (Occupied: } 0.7 \mathrm{Vol} / \mathrm{h} \text {, } \\
\text { Unoccupied: } 0.2) \text {. } \\
\text {-LHTES Cooling } \\
\text { system (nominal air } \\
\text { flow rate of } 250 \mathrm{~m}^{3} / \mathrm{h} \text {, } \\
\text { corresponding to } 2.61 \\
\text { ACH) } \\
\text {-Air cooler }(121 \mathrm{~b}) \\
\text {-Air heater }(92 \mathrm{~b})\end{array}$ \\
\hline $\begin{array}{l}\text { Lighting system and } \\
\text { lighting control }\end{array}$ & \multicolumn{3}{|c|}{$\begin{array}{c}\text { Lighting: } 10 \mathrm{~W} / \mathrm{m}^{2} \text {, functioning during occupancy }(\mathrm{ON} / \mathrm{OFF} \\
\text { Control) }\end{array}$} \\
\hline HVAC Control & $\begin{array}{c}\text { Functioning } \\
\text { during } \\
\text { occupancy } \\
\text { (ON/OFF) }\end{array}$ & $\begin{array}{c}\text { Functioning during } \\
\text { occupancy } \\
\text { (ON/OFF) }\end{array}$ & BEMS $(\S 2.31)$ \\
\hline Occupancy & \multicolumn{3}{|c|}{3 persons } \\
\hline Equipment & \multicolumn{3}{|c|}{ Equipment: $230 \mathrm{~W} /$ person } \\
\hline $\begin{array}{l}\text { Building and equipment } \\
\text { operating hours }\end{array}$ & \multicolumn{3}{|c|}{$\begin{array}{c}\text { Weekdays: } 8 \text { a.m-6 p.m; Weekend: no operation (Office } \\
\text { operation) }\end{array}$} \\
\hline Temperature settings: & \multicolumn{3}{|c|}{$\begin{array}{l}\text { Heating set-point: } 26{ }^{\circ} \mathrm{C} \text {, Cooling set-point: } 21{ }^{\circ} \mathrm{C} \text {, Dead- } \\
\text { band: } 1^{\circ} \mathrm{C} \text {. }\end{array}$} \\
\hline
\end{tabular}

Table 11: Building characteristics and design conditions.

Table 12 presents the heating and cooling loads for the three cases and the potential energy savings. The energy saving depends on the severity of the climate as already addressed above. Compared to the reference building, the traditional retrofitting solution saves around $8 \%$ of the overall energy loads in average while the E2VENT solution can save around $25 \%$ of the overall energy loads. The E2VENT solution is therefore three times high in energy recovery efficiency compared to the traditional retrofitting solution, mainly owing to the high energy efficiencies of the SMHRU and LHTES.

\begin{tabular}{|l|c|c|c|c|c|c|c|c|c|c|c|}
\hline & Building reference & \multicolumn{2}{c|}{ Traditional solution } & \multicolumn{2}{c|}{ E2VENT solution } & \multicolumn{2}{c|}{ Total loads [kWh/m2 $]$} & \multicolumn{2}{c|}{ Load saving } \\
\cline { 2 - 12 } & $\begin{array}{c}\text { Heating } \\
{[\mathrm{kWh} / \mathrm{m} 2]}\end{array}$ & $\begin{array}{c}\text { Cooling } \\
{[\mathrm{kWh} / \mathrm{m} 2]}\end{array}$ & $\begin{array}{c}\text { Heating } \\
{[\mathrm{kWh} / \mathrm{m} 2]}\end{array}$ & $\begin{array}{c}\text { Cooling } \\
{[\mathrm{kWh} / \mathrm{m} 2]}\end{array}$ & $\begin{array}{c}\text { Heating } \\
{[\mathrm{kWh} / \mathrm{m} 2]}\end{array}$ & $\begin{array}{c}\text { Cooling } \\
{[\mathrm{kWh} / \mathrm{m} 2]}\end{array}$ & $\begin{array}{c}\text { Building } \\
\text { reference }\end{array}$ & $\begin{array}{c}\text { Traditional } \\
\text { solution }\end{array}$ & $\begin{array}{c}\text { E2VENT } \\
\text { solution }\end{array}$ & $\begin{array}{c}\text { Traditional } \\
\text { solution }\end{array}$ & $\begin{array}{c}\text { E2VENT } \\
\text { solution }\end{array}$ \\
\hline ATHENS & $\mathbf{9 . 0}$ & $\mathbf{2 9 . 7}$ & $\mathbf{7 . 3}$ & $\mathbf{2 9 . 5}$ & $\mathbf{5 . 4}$ & $\mathbf{2 6 . 3}$ & $\mathbf{3 8 . 7}$ & $\mathbf{3 6 . 9}$ & $\mathbf{3 1 . 7}$ & $\mathbf{4 . 7 \%}$ & $\mathbf{1 8 . 1 \%}$ \\
\hline MADRID & $\mathbf{2 5 . 5}$ & $\mathbf{1 6 . 8}$ & $\mathbf{2 2 . 8}$ & $\mathbf{1 6 . 5}$ & $\mathbf{1 6 . 6}$ & $\mathbf{1 3 . 7}$ & $\mathbf{4 2 . 3}$ & $\mathbf{3 9 . 4}$ & $\mathbf{3 0 . 3}$ & $\mathbf{7 . 1 \%}$ & $\mathbf{2 8 . 4 \%}$ \\
\hline PARIS & 47.6 & 1.1 & $\mathbf{4 2 . 6}$ & $\mathbf{0 . 9}$ & $\mathbf{3 3 . 9}$ & $\mathbf{0 . 5}$ & $\mathbf{4 8 . 6}$ & $\mathbf{4 3 . 4}$ & $\mathbf{3 4 . 4}$ & $\mathbf{1 0 . 7 \%}$ & $\mathbf{2 9 . 2 \%}$ \\
\hline GDANSK & $\mathbf{7 1 . 1}$ & $\mathbf{0 . 0}$ & $\mathbf{6 4 . 4}$ & $\mathbf{0 . 0}$ & $\mathbf{5 2 . 9}$ & $\mathbf{0 . 0}$ & $\mathbf{7 1 . 2}$ & $\mathbf{6 4 . 4}$ & $\mathbf{5 2 . 9}$ & $\mathbf{9 . 5 \%}$ & $\mathbf{2 5 . 7 \%}$ \\
\hline STOCKHOLM & $\mathbf{8 4 . 7}$ & $\mathbf{0 . 1}$ & $\mathbf{7 8 . 0}$ & $\mathbf{0 . 1}$ & $\mathbf{6 5 . 0}$ & $\mathbf{0 . 1}$ & $\mathbf{8 4 . 8}$ & $\mathbf{7 8 . 1}$ & $\mathbf{6 5 . 0}$ & $\mathbf{8 . 0 \%}$ & $\mathbf{2 3 . 3 \%}$ \\
\hline
\end{tabular}

Table 12: Final energy heating and cooling load savings for three cases: building reference, building with usual solution and building with E2VENT solution 
By converting the final energy into the primary fossil fuel energy, the energy saving figure is somehow decreased, especially for the building with E2VENT system (Table 13). In fact, the building with the E2VENT solution is more penalized by the electricity consumption. Figure 23 presents the total electricity consumption for the three cases. The energy saving is significantly reduced owing to the electrical energy consumption of the E2VENT Fans (2 for the LHTES and 2 for the SMHRU). However, despite this electrical energy consumption impact, the building with The E2VENT solution can still saves 2 times primary fossil fuel energy that the traditional solution $(9.6 \%$.vs. $4.5 \%)$. The optimization of the electrical energy consumption of the SMHRU and LHTES can significantly increase the energy efficiency of the E2VENT system.

\begin{tabular}{|c|c|c|c|c|c|c|c|c|c|c|c|}
\hline \multirow[b]{2}{*}{ Location } & \multicolumn{2}{|c|}{ Building reference } & \multicolumn{2}{|c|}{ Traditional solution } & \multicolumn{2}{|c|}{ E2VENT solution } & \multicolumn{3}{|c|}{ Total loads [kWh/m2] } & \multicolumn{2}{|c|}{ Load saving } \\
\hline & $\begin{array}{c}\text { Heating } \\
{[\mathrm{kWh} / \mathrm{m} 2]}\end{array}$ & $\begin{array}{c}\text { Cooling } \\
{[\mathrm{kWh} / \mathrm{m} 2]}\end{array}$ & $\begin{array}{c}\text { Heating } \\
{[\mathrm{kWh} / \mathrm{m} 2]}\end{array}$ & $\begin{array}{c}\text { Cooling } \\
{[\mathrm{kWh} / \mathrm{m} 2]}\end{array}$ & \begin{tabular}{|c|} 
Heating \\
{$[\mathrm{kWh} / \mathrm{m} 2$}
\end{tabular} & $\begin{array}{c}\text { Cooling } \\
{[\mathrm{kWh} / \mathrm{m} 2]}\end{array}$ & $\begin{array}{c}\text { Building } \\
\text { reference }\end{array}$ & $\begin{array}{c}\text { Traditional } \\
\text { solution } \\
\end{array}$ & $\begin{array}{c}\text { E2VENT } \\
\text { solution }\end{array}$ & \begin{tabular}{|c|} 
Traditional \\
solution \\
\end{tabular} & \begin{tabular}{|c|} 
E2VENT \\
solution \\
\end{tabular} \\
\hline ATHENS & 9.0 & 25.6 & 7.3 & 25.4 & 5.4 & 22.6 & 72.6 & 71.6 & 70.6 & $1.4 \%$ & $2.8 \%$ \\
\hline MADRID & 25.5 & 14.5 & 22.8 & 14.2 & 16.6 & 11.8 & 79.4 & 76.5 & 71.3 & $3.7 \%$ & $10.3 \%$ \\
\hline PARIS & 47.6 & 0.9 & 42.6 & 0.7 & 33.9 & 0.5 & 84.8 & 79.7 & 75.5 & $6.1 \%$ & $11.0 \%$ \\
\hline GDANSK & 71.1 & 0.0 & 64.4 & 0.0 & 52.9 & $\mathbf{0 . 0}$ & 108.4 & 101.9 & 95.5 & $6.0 \%$ & $11.9 \%$ \\
\hline STOCKHOLM & 84.7 & 0.1 & 78.0 & 0.1 & 65.0 & 0.1 & 122.7 & 116.4 & 108.1 & $5.1 \%$ & $11.9 \%$ \\
\hline & & & & & & Average & 93.6 & 89.2 & 84.2 & $4.5 \%$ & $9.6 \%$ \\
\hline
\end{tabular}

Table 13: Primary energy heating and cooling loads saving for the three cases:

Building reference, building with usual solution and building with E2VENT solution

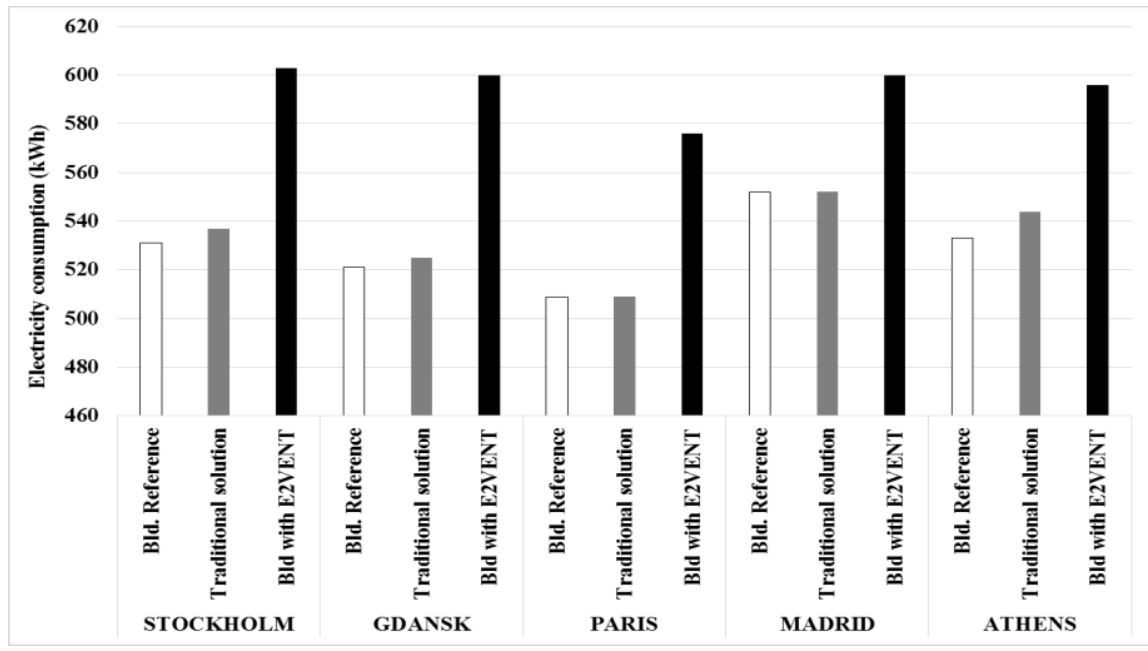

Fig. 23: Electricity consumption of the building for the three cases:

Building reference, building with usual solution and building with E2VENT solution

\section{Conclusions}


In this paper, the energy model for an innovative E2VENT ventilated façade incorporating a heat recovery system and a LHTES unit was developed. The energy efficiency of the ventilated system was illustrated in a case study for five climates in Europe. The results show that the new E2VENT ventilated façade can improve the thermal comfort and has potential to save significant primary fossil fuel energy at all climatic conditions.

The efficiency of the E2VENT energy system is largely dependent upon the severity of the climate. The SMHRU system can operate effectively during the whole heating and cooling periods, while the LHTES system is only effective during the cooling period. This indicates that the electrical energy consumed by the fan within the system is non-negligible and could penalize the system if it is not appropriately optimized. Moreover, the infiltration rate can make a significant impact on the energy efficiency of the system.

Comparison between the traditional and E2VENT retrofitting solutions is undertaken to assess the energy performance of the E2VENT system against the traditional one. This indicates that the E2VENT system can achieve two times higher primary fossil fuel energy saving compared to the traditional retrofitting method, although the E2VENT system is somehow penalized by the higher electrical energy consumption. An optimisation towards the E2VENT system targeting to minimise its electrical energy consumption could significantly increase the energy efficiency of the system. On these bases, the global model derived from the research can be used to optimize all the main parameters that can effectively enhance the efficiency of the system, thus contributing to significant fossil fuel energy saving and carbon emission of the building through a dedicated retrofitting process.

\section{Acknowledgements}

This work has been developed under the research project "E2VENT: Energy Efficient Ventilated Façades" funded by the Horizon 2020 framework of the European Union, Project No. 637261. http://e2vent.eu/

\section{References}


[1] M.A. Shameri, M.A, Alghoul, K. Sopian, M. Fauzi, M. Zaina, O.Elayebb. Perspectives of double skin facade systems in buildings and energy saving. Renewable and Sustainable Energy Reviews 15 (2011) 1468-1475.

[2] S. Barbosa, K. Ip. Perspectives of double skin façades for naturally ventilated buildings: a review. Renew Sustain Energy Rev 2014; 40:1019-29.

[3] G. Quesada, D. Rousse, Y. Dutil, M. Badache, S. Hallé. A comprehensive review of solar facades. Opaque solar facades. Renew Sustain Energy Rev 2012; 16:2820-32.

[4] J. Peng , C. Curcija Dragan. ,S.E Selkowitz. H. Yang, W. Zhang, Numerical investigation of the energy saving potential of a semi-transparent photovoltaic double-skin facade in a cool-summer Mediterranean climate, Applied Energy Volume 165, 1 March 2016, Pages 345-356.

[5] H. Dehra, An investigation on energy performance assessment of a photovoltaic solar wall under buoyancy-induced and fan-assisted ventilation system. Applied Energy, Volume 191, 1 April 2017, Pages 55-74.

[6] M.A. Leon, S. Kumar. Mathematical modelling and thermal performance analysis of unglazed transpired solar collectors. Sol Energy 2007;81:62-75.

[7] D.J. Harris, N. Helwig. Solar chimney and building ventilation. Appl. Energy 2007; $84: 135-46$.

[8] R. Khanal, C.Lei. Solar chimney - a passive strategy for natural ventilation. Energy Build 2011; 43:1811-9.

[9] O. Saadatian, K. Sopian,C.H. Lim, N. Asim, M.Y.Sulaiman. Trombe walls: a review of opportunities and challenges in research and development. Renew Sustain Energy Rev 2012;16:6340-51.

[10] M. Ibañez-Puy,M. Vidaurre-Arbizu, J.A Sacristán-Fernández ,C. Martín-Gómez, Opaque Ventilated Façades: Thermal and energy performance review. Renewable and Sustainable Energy Reviews Volume 79, November 2017, Pages 180-191.

[11] F.P. López and M. Ruiz de Adana Santiago. Sensitivity study of an opaque ventilated façade in the winter season in different climate zones in Spain. Renewable Energy 75 (2015).

[12] F.P. López, R.L. Jensen, P. Heiselberg, M. Ruiz de Adana Santiago, Experimental analysis and model validation of an opaque ventilated façade, Building Environment 56 (2012).

[13] C. Aparicio-Fernández, J.L Vivancos, P. Ferrer-Gisbert, R. Royo-Pastor. Energy performance of a ventilated façade by simulation with experimental validation. Applied Thermal Engineering 66 (2014).

[14] F. Patania, A. Gagliano, F. Nocera, A. Ferlito, A. Galesi. Thermofluid-dynamic analysis of ventilated facades. Energy Build 2010; 42:1148-55. 
[15] M. Ciampi, F. Leccese, G. Tuoni. Ventilated facades energy performance in summer cooling of buildings. Sol Energy 2003; 75:491-502.

[16] C. Balocco. A simple model to study ventilated facades energy performance. Energy Build 2002; 34:469-75.

[17] C. Sanjuan, M.J. Suárez, M. González, J. Pistono, E. Blanco. Energy performance of an open-joint ventilated façade compared with a conventional sealed cavity façade. Sol Energy 2011; 85:1851-63.

[18] A. Gagliano,F. Nocera, S. Aneli. Thermodynamic analysis of ventilated façades under different wind conditions in summer period. Energy Build 2016;122:131-9.

[19] G. Diarce, A. Urresti. A. García-Romero, A. Delgado, A. Campos-Celador. Ventilated active façades with PCM, Applied Energy, Volume 109, September 2013, Pages 530-537.

[20] A. De Gracia , L. Navarro , A.Castell, L. F. Cabeza, Numerical study on the thermal performance of a ventilated facade with PCM, Applied Thermal Engineering 61 (2013) $372 \mathrm{e} 380$.

[21] A. Gracia, L. Navarroa, A. Castell, Á. Ruiz-Pardo, S. Alvárez , L. F. Cabezaa, Experimental study of a ventilated facade with PCM during winter period, Energy and Buildings 58 (2013) 324-332.

[22] A. Martinez I. Urra, J. Hernandez, T.M.O. Diallo, X. Zhao. Development of a Smart Modular Heat Recovery Unit adaptable into a ventilated façade. International Conference on Sustainable Synergies from Buildings to the Urban Scale, SBE16. Procedia Environmental Sciences 38 (2017) $94-101$.

[23] A. Dugué, S. Raji, P. Bonnamy, D. Bruneau. E2VENT: an energy efficient ventilated façade retrofitting system. Presentation of the embedded LHTES system. International Conference on Sustainable Synergies from Buildings to the Urban Scale, SBE16. Procedia Environmental Sciences, Volume 38, 2017, Pages 121-129.

[24] Rouault, F., Bruneau, D., Sebastian, P., \& Lopez, J. (2013). Numerical modelling of tube bundle thermal energy storage for free-cooling of buildings. Applied Energy, 111, 1099-1106.

[25] F. P. Incropera \& D. P. DeWitt 1990 Fundamentals of Heat and Mass Transfer, 3rd edition, pp. 658-660. Wiley, New York.

[26] H. A. Luther, An explicit sixth-order Runge-Kutta formula, Math. Comp. 22 (1968), 344

[27] V. Iván Serna González, J. Luis Hernández García, Á. Corredera Cano,Francisco Javier Miguel Herrero, Roberto Sanz Jimeno, Jesús García Domínguez, Bems para control inteligente de fachadas ventiladas. II Congreso de Edificios Inteligentes." Madrid. 27-28 Octubre 2015.

[28] TRNSYS documentation, "TRNSYS 17: A Transient System Simulation Programme Volume 4 Mathematical Reference," the documentations attached in the software package of TRNSYS 17 for the Standard Component Library. 
[29] Type 1230 TRNSYS, Duffie J.A., Beckman W.A. (2013). Solar Engineering of Thermal Processes. ISBN: 978-0-470-87366-3: Wiley and Sons.

[30] Grau, K., Rode, C., 2006," A model for airflow in ventilated cavities implemented in a tool for whole -building hydrothermal analysis", Annual report year: 2006, Danish Building Research Institute.

[31] T.Theodosiou, K.Tsikaloudaki, D.Bikas, Analysis of the thermal bridging effect on ventilated facades, International Conference on Sustainable Synergies from Buildings to the Urban Scale, SBE16, 17-19 Oct. 2016, Thessaloniki, Greece - Under publication in "Procedia Environmental Sciences".

[32] T.G.Theodosiou, E. G. Tsikaloudaki, K.J. Kontoleon, D.K. Bikas, Thermal bridging analysis on cladding systems for building facades, Energy and Buildings, Issue 109, 2015, pages 377-384.

[33] EN ISO 10211, Thermal bridges in building construction - Heat flows and surface temperatures - Detailed calculations, (2007) 54.

[34] K. Martin, C. Escudero, A. Erkoreka, I. Flores, J.M. Sala, Equivalent wall method for dynamic characterisation of thermal bridges, Energy Build. 55 (2012) 704-714.

[35] EN, 13779 Ventilation for non-residential buildings-Performance requirements for ventilation and room-conditioning systems. European Standard CEN/TC 156,2006-07.

[36] C.A Roulet, F.D. Heidt, F.Foradini, M.C. Pibiri, Real Heat Recovery with air handling units, Energy and buildings 33 (5) 2001 45-502.

[37] Silvia Guillén-Lambea, Beatriz Rodríguez-Soria, José M. Marín (2016), Review of European ventilation strategies to meet the cooling and heating demands of nearly zero energy buildings (nZEB)/Passivhaus. Comparison with the USA. Renewable and Sustainable Energy Reviews. Renewable and Sustainable Energy Reviews 62(2016)561-574. 